\title{
Feasibility of two low-cost organic substrates for inducing denitrification in artificial recharge ponds: Batch and flow-through experiments
}

\author{
Alba Grau-Martínez ${ }^{\left(a,{ }^{*}\right)}$, Clara Torrentó ${ }^{(a, b)}$, Raúl Carrey ${ }^{(a)}$, Paula Rodríguez-Escales ${ }^{(\mathrm{C}) \text {, }}$ \\ Cristina Domènech ${ }^{(a)}$, Giorgio Ghiglieri ${ }^{(\mathrm{d}, \mathrm{e})}$, Albert Soler ${ }^{(\mathrm{a})}$, Neus Otero ${ }^{(\mathrm{a})}$
}

(a) Grup de Mineralogia Aplicada i Geoquímica de Fluids, Departament de Mineralogia, Petrologia i Geologia Aplicada, SIMGEO UB-CSIC, Facultat de Geologia, Universitat de Barcelona (UB), C/ Martí i Franquès, s/n - 08028 Barcelona, Spain. albagrau@ub.edu, clara.torrento@ub.edu, raulcarrey@ub.edu, cristina.domenech@ub.edu, albertsoler@ub.edu, notero@ub.edu

(b) Centre for Hydrogeology and Geothermics, University of Neuchâtel, 2 Rue Emile-Argand 11, 2000 Neuchâtel, Switzerland. clara.torrento@unine.ch

(c) Hydrogeology Group (GHS). Departament of Civil and Environmental Engineering, Universitat Politècnica de Catalunya (UPC), c/Jordi Girona 1-3, 08034 Barcelona, Spain. paula.rodriguez.escales@upc.edu

(d) Department of Chemical and Geological Sciences, University of Cagliari, Via Trentino 51, 09127 Cagliari, Italy. ghiglieri@unica.it

(e) Desertification Research Center-NRD, University of Sassari, Viale Italia 39 - 07100 Sassari, Italy

(*) Corresponding author: Alba Grau-Martínez

e-mail: albagrau@ub.edu

Fax: +34 934021340 .

Phone: +34 934033773 ext: 33773 


\section{FEASIBILITY OF TWO LOW-COST ORGANIC}

2 SUBSTRATES FOR INDUCING DENITRIFICATION

3 IN ARTIFICIAL RECHARGE PONDS: BATCH AND

4 FLOW-THROUGH EXPERIMENTS

5 Alba Grau-Martínez ${ }^{\mathrm{a}^{\star}}$, Clara Torrentóa,b, Raúl Carreya ${ }^{\mathrm{a}}$, Paula Rodríguez-Escales $^{c}$,

6 Cristina Domènech ${ }^{\mathrm{a}}$, Giorgio Ghiglierid,e ${ }^{\mathrm{d}}$, Albert Soler ${ }^{\mathrm{a}}$, Neus Otero ${ }^{\mathrm{a}}$ 7

8 Keywords

9 Denitrification, permeable reactive barrier, monitored artificial recharge, organic 10 substrate, flow-through experiments, semi-arid region.

\section{Introduction}

Nitrate $\left(\mathrm{NO}_{3}{ }^{-}\right)$contamination of groundwater usually originates from anthropogenic sources (mainly intensive application of fertilisers and animal manure), and is a major environmental problem that affects several regions of the world (Spalding and Exner, 1993). It is not unusual for groundwater $\mathrm{NO}_{3}{ }^{-}$concentrations to exceed the nominal limit of $50 \mathrm{mg} \mathrm{L}^{-1}$ for drinking water set by the 98/83/EC European Union Council Directive. High $\mathrm{NO}_{3}{ }^{-}$ingestion can cause methemoglobinaemia in infants and young children (Magee and Barnes, 1956) and may also promote stomach cancer. Although $\mathrm{NO}_{3}{ }^{-}$ contamination of aquifers is a serious environmental and health issue, natural denitrification can occur, reducing pollution levels and diminishing the severity of the problem. This process is considered to be the most important reaction that attenuates $\mathrm{NO}_{3}{ }^{-}$in groundwater (Knowles, 1982). Denitrification may be defined as the dissimilatory microbial reduction of $\mathrm{NO}_{3}{ }^{-}$to nitrogen gas $\left(\mathrm{N}_{2}\right)$ through several intermediate steps (Eq. 1).

$$
\mathrm{NO}_{3}^{-} \rightarrow \mathrm{NO}_{2}^{-} \rightarrow \mathrm{NO} \rightarrow \mathrm{N}_{2} \mathrm{O} \rightarrow \mathrm{N}_{2}
$$

Denitrification takes place under anaerobic conditions where bacteria use $\mathrm{NO}_{3}{ }^{-}$as an oxidant for different materials such as organic matter, sulphides and iron minerals. 
1 Denitrification can proceed by the action of heterotrophic or autotrophic bacteria, which

2 oxidise organic or inorganic substrates, respectively (simplified Eq. 2, 3). In both cases,

$3 \mathrm{NO}_{3}{ }^{-}$is first transformed into nitrite $\left(\mathrm{NO}_{2}{ }^{-}\right)$, which is actually more toxic than $\mathrm{NO}_{3}{ }^{-}$(DeBeer

4 et al., 1997), with a maximum concentration in drinking water of $0.46 \mathrm{mg} \mathrm{L}^{-1}$ (Directive

5 98/83/CE). Through successive steps, $\mathrm{NO}_{2}^{-}$is transformed into nitric oxide (NO), which

6 can further be reduced to nitrous oxide $\left(\mathrm{N}_{2} \mathrm{O}\right)$; both species are considered greenhouse

7 gases. Finally, $\mathrm{N}_{2} \mathrm{O}$ is converted to harmless $\mathrm{N}_{2}$.

8

9

$$
\begin{aligned}
& 5 \mathrm{CH}_{2} \mathrm{O}+4 \mathrm{NO}_{3}^{-}+4 \mathrm{H}^{+} \rightarrow 2 \mathrm{~N}_{2}+5 \mathrm{CO}_{2}+7 \mathrm{H}_{2} \mathrm{O} \\
& 5 \mathrm{FeS}_{2}+14 \mathrm{NO}_{3}^{-}+4 \mathrm{H}^{+} \rightarrow 7 \mathrm{~N}_{2}+10 \mathrm{SO}_{4}^{2-}+5 \mathrm{Fe}^{2+}+2 \mathrm{H}_{2} \mathrm{O}
\end{aligned}
$$

Under anaerobic conditions, nitrate may also be reduced to ammonium $\left(\mathrm{NH}_{4}{ }^{+}\right)$by a process known as dissimilatory $\mathrm{NO}_{3}{ }^{-}$reduction to $\mathrm{NH}_{4}{ }^{+}$(DNRA or ammonification). DNRA is induced by fermentative bacteria, reducing $\mathrm{NO}_{3}{ }^{-}$to $\mathrm{NO}_{2}{ }^{-}$before a final reduction to $\mathrm{NH}_{4}{ }^{+}$(Tiedje et al., 1982).

When anoxic or hypoxic conditions are guaranteed, the main limitation of natural attenuation of NO3- is the lack or limited availability of electron donors (Knowles, 1982). Furthermore, the presence of inorganic electron donors, such pyrite, is not abundant. Thus, both autotrophic and heterotrophic denitrification processes are usually limited. For this reason, the most common strategy to remediate $\mathrm{NO}_{3}{ }^{-}$contamination from point source discharges has been the addition of an external electron donor into the system in order to enhance the capacity of indigenous denitrifying biomass to reduce $\mathrm{NO}_{3}{ }^{-}$into dinitrogen gas (Leverenz, et al., 2010; Vidal-Gavilan, et al., 2013). For economical, practical and environmental reasons, an organic carbon source is the most common external electron donor added to the system. Organic carbon can be incorporated into the aquifer via active systems such as injection wells (e.g. Vidal-Gavilan et al., 2013) or passive systems such as permeable reactive barriers, PRBs (Gibert et al., 2008; Robertson et al., 2008).

In arid and semi-arid regions, managed aquifer recharge (MAR) is a widely used technique to increase water supplies. Infiltration and artificial recharge are achieved by 
1 ponding or flowing water on the soil surface with basins, furrows, ditches or ponds

2 (Bouwer, 2002). Artificial recharge ponds (ARP) require excavation of permeable terrain

3 close to the water source (river channel, effluent from a water treatment plant (WTP),

4 etc.). A decantation pond is often included in these systems to improve water quality

5 through deposition of suspended solids. Additionally, in order to improve the quality of

6 both recharged and groundwater, the infiltration ponds can be coupled with a PRB, e.g.

7 an organic reactive layer at the bottom of the pond. The release of organic carbon into

8 the system is expected to enhance endogenous microbiology activity, improving the

9 natural attenuation rate of some target pollutants.

10 A good example of ARP coupled with PRB is located in Sant Vicenç dels Horts 11 (Barcelona, Spain), where the aquifer is recharged by Llobregat River water. Several studies have shown that the organic reactive layer in this ARP has improved elimination of some organic contaminants (Valhondo et al., 2014). One of the key design parameters in ARP-PRB facilities is the type of material in the reactive layer. This should be effective, economic and easily available. Furthermore, it must be adapted to the socioeconomic circumstances of each country. In several source water used for MAR purposes, such as treated wastewater, the presence of not only $\mathrm{NO}_{3}{ }^{-}$, but also $\mathrm{NH}_{4}{ }^{+}, \mathrm{N}$-organic compounds and other organic micropollutants, might affect the suitability of these sources for using as recharge water (Miller et al., 2006; Díaz-Cruz and Barceló, 2008; Kuster et al., 2010; Maeng et al., 2011). The main organic N-containing compounds 21 present in effluents of water treatment plants are amino acids, ethylenediaminetetraacetic acid (EDTA), disinfection by-products, humic substances, pharmaceuticals and pesticides (Pehlivanoglu-Mantas and Sedlak, 2008; Westgate and Park, 2010). Therefore, MAR might significantly lower the concentration of these contaminants present in the source water (Bekele et al., 2011). For sustainable groundwater management, the attenuation and fate of these compounds in groundwater environments during MAR must be evaluated for each specific recharge site. In the framework of the project entitled "Water harvesting and Agricultural techniques in 
1 Dry lands: an Integrated and Sustainable model in Maghreb Regions" (WADIS-MAR, 2 www.wadismar.eu) a MAR system consisting of ARP with an organic reactive layer will

3 be installed in the Maghreb region (in the watersheds of Oued Biskra, Algeria). The area

4 is characterized by poor soil development, low organic matter content, water scarcity,

5 increasing water demand, overexploitation of groundwater resources and high exposure

6 to nitrate contamination. In this area, recharge is mainly due to short, heavy floods

7 caused by erratic and intense short-term rainfall events (Ghiglieri et al., 2014). Before

8 implementing the ARP in the Maghreb region, laboratory feasibility tests were carried out

9 to select the best viable substrate for the reactive layer and to evaluate its capacity to remove $\mathrm{NO}_{3}{ }^{-}$. Several organic substrates, such as compost and softwood, had previously been evaluated for their use in denitrification PRBs (Gibert et al., 2008). In this study, we sought to identify low-cost, easily available and easily handled organic substrates with the capacity to rapidly enhance denitrification in reactive layers in ARPs located in arid and semi-arid regions, where groundwater recharge periods are typically short. Bearing the above criteria in mind, we selected palm tree leaves and compost, the former because palm trees are typical flora in arid North African regions and the latter to serve for comparison with ARPs in moderate to humid regions such as Sant Vicenç dels Horts.

Isotopic studies coupled with chemical data are an effective tool to identify and describe denitrification (Aravena and Robertson, 1998). Furthermore, multi-isotopic studies of the solutes involved in the reactions, such as the $\delta^{13} \mathrm{C}$ of dissolved inorganic carbon and the $\delta^{34} S$ and $\delta^{18} \mathrm{O}$ of dissolved sulphate, can help determine whether denitrification is promoted by heterotrophic or autotrophic bacteria and identify the existence of secondary processes such as $\mathrm{SO}_{4}{ }^{2-}$ reduction (Mariotti et al., 1988). The major goal of this study was therefore to assess the denitrification capacity of two substrates for their potential use in ARPs. To this end, laboratory batch and column experiments were performed. The possible adverse effects, such as $\mathrm{NO}_{2}{ }^{-}$accumulation, $\mathrm{NH}_{4}{ }^{+}$formation and sulphate reduction, were also considered and characterised using 
1 isotopic and modelling tools. The second goal of this study was to obtain the nitrogen

2 and oxygen isotope fractionations associated with the studied degradation processes to

3 evaluate their potential use as a tool for assessing the efficiency of future enhanced

4 denitrification activities at field scale.

\section{Experimental set-up and methods}

\section{2.1. Experimental set-up}

7 Batch and flow-through experiments were performed with the two materials tested, commercial compost from a composting plant located in Moià (Catalonia, NE Spain) and

9 palm tree leaves from the Maghreb region (the watersheds of Oued Biskra in Algeria).

10 Both substrates consisted of irregular pieces of organic material between 0.3 and $2 \mathrm{~cm}$

11 in size and were used without any specific pre-treatment. The amount of $N$ and $C(\%)$ as

12 well as the $\delta^{15} \mathrm{~N}(\%)$ and $\delta^{13} \mathrm{C}(\%)$ of both substrates was characterised (Table 1).

13 The groundwater used in all the experiments was from the Llobregat aquifer. This was 14 chosen because it is chemically comparable (Soler et al. 2016) to the watersheds of Oued Biskra in Algeria groundwater and it significantly facilitated and reduced the cost of the experiment. All the experiments were performed in a glove box with an argon

17 (batch experiments) or nitrogen (flow-though) atmosphere to avoid the presence of $\mathrm{O}_{2}$.

18 Experimental oxygen partial pressure in the glove box was maintained between $0.1 \%$ and $0.3 \% \mathrm{O}_{2}$, and was continuously monitored by an oxygen partial pressure detector (Sensotran, Gasvisor 6) with an accuracy of $\pm 0.1 \% \mathrm{O}_{2}$. Four types of batch experiment were performed in sterilised $500 \mathrm{~mL}$ glass bottles. Groundwater, spiked with $\mathrm{NaNO}_{3}$ in varying amounts, was added to the glass bottles (Table 2). Commercial compost batch (CCB) and palm tree leaves batch (PTB) experiments were run in triplicate using the selected material and groundwater spiked with $0.80 \mathrm{mM}$ of $\mathrm{NO}_{3}{ }^{-}$previously purged with $\mathrm{N}_{2}$ for 15 min. A 'sterilised control' experiment (SCB) was carried out adding autoclaved material (palm tree leaves) to autoclaved groundwater which had been previously degassed. In addition, an 'absence 
1 control' experiment (ACB) was carried out using only degassed groundwater. Batch

2 experiments with palm tree leaves lasted for 24 hours, whereas those with commercial

3 compost lasted 11 days. In the case of the experiments with compost, bottles were

4 manually shaken once a day while in the case of the experiments with palm tree leaves,

5 bottles were shaken before each sampling event. Aqueous samples $(5 \mathrm{~mL})$ were

6 periodically collected using sterile syringes. The number of samples was limited to

7 maintain the solution: solid material ratio at $90 \%$ of initial value.

8 The two flow-through experiments were carried out using glass cylindrical columns (35

$9 \mathrm{~cm}$ high, $9 \mathrm{~cm}$ inner diameter) (Supplementary material, Figure S1). The commercial compost column (CCC) was filled with $1.24 \mathrm{~kg}$ of compost mixed with $3.34 \mathrm{~kg}$ of clean silica sand (Panreac $®)$ to increase permeability and prevent flotation of the reactive material. The palm tree column (PTC) was filled with $134 \mathrm{~g}$ of palm tree leaves mixed with $3.36 \mathrm{~kg}$ of clean silica sand. Thus, total organic C was 40.6 and $18.2 \mathrm{~g} \mathrm{~kg}^{-1}$ for CCC and PTC experiments, respectively. In both experiments, the bottom of the column was filled with silica balls $(2 \mathrm{~mm} \varnothing)$ to prevent sediment clogging the outlet. From the results of a bromide tracer test performed just before the start of the experiments, porosity (45\% and $28 \%)$ and pore volume $(0.77 \mathrm{~L}$ and $0.52 \mathrm{~L})$ were estimated for the $\mathrm{CCC}$ and the PTC experiments, respectively. The columns were filled with water leaving a $4.5 \mathrm{~cm}$ free nappe over the sediment to prevent the occurrence of a preferential flow pathway. Both columns operated in downflow mode and the flow rate was controlled by a peristaltic pump (Micropump Reglo Digital 4 channels ISMATEC). In both experiments, two stages were defined separated by a lag period with no flow during which the columns were dried and kept in the glove box. This lag period was used to simulate a dry period in an artificial recharge set-up. During both stages (I and II), flow rate varied from $0.2 \mathrm{~mL} \mathrm{~min}^{-1}$ to 0.4 $\mathrm{mL} \mathrm{min}^{-1}$. The duration and flow rates of each stage are detailed later in this paper for the CCC and PTC experiments, respectively. The input water was spiked with a $\mathrm{NaNO}_{3}$ solution to achieve a known nitrate concentration of between $0.8 \mathrm{mM}$ and $2.9 \mathrm{mM}$ for the CCC experiment and between $0.7 \mathrm{mM}$ and $3.5 \mathrm{mM}$ for the PTC experiment. 
1 Both flow-through experiments lasted over 7 months and 76 and 56 samples were

2 collected from the outlet of the CCC and PTC, respectively.

\section{$3 \quad$ 2.2. Analytical methods}

4 Anion $\left(\mathrm{NO}_{3}{ }^{-}, \mathrm{NO}_{2}{ }^{-}, \mathrm{Cl}^{-}\right.$and $\left.\mathrm{SO}_{4}{ }^{2-}\right)$ concentrations and isotope ratios $\left(\delta^{15} \mathrm{~N}\right.$ and $\delta^{18} \mathrm{O}$ of 5 dissolved $\mathrm{NO}_{3}{ }^{-}$) were measured in all the batch experiment samples. In the flow-through 6 experiments, anions, cations, $\mathrm{NH}_{4}{ }^{+}$, non-purgeable dissolved organic carbon (NPDOC) 7 and dissolved inorganic carbon (DIC) were measured, and isotopic data were 8 determined for a subset of samples considered representative according to the 9 measured concentration of the target analyses. Redox potential (Eh) and $\mathrm{pH}$ were measured daily at the column outflow with portable electrodes (WTW-3310). Aliquots of aqueous samples were filtered through $0.2 \mu \mathrm{m}$ Millipore ${ }^{\circledR}$ filters. Anion concentration was determined by high performance liquid chromatography (HPLC) with a WATERS 515 HPLC pump, IC-PAC anion columns and a WATERS 432 detector. For major cation analysis, samples were acidified with $1 \% \mathrm{HNO}_{3}{ }^{-}$. Cation concentrations were determined by inductively coupled plasma-optical emission spectrometry (ICP-OES, Perkin-Elmer Optima $3200 \mathrm{RL}$ ). $\mathrm{NH}_{4}{ }^{+}$was analysed using ionic chromatography (DIONEX, ICS5000). NPDOC was measured by organic matter combustion using a MULTI N/C 3100 Analytik Jena carbon analyser. Periodically, $25 \mathrm{~mL}$ of aqueous solution was sampled to measure dissolved inorganic carbon (DIC) by titration (METROHM 702 SM Titrino). Chemical analyses were conducted at the the "Centres Científics i Tecnològics" of the Universitat de Barcelona (CCiT-UB). Stable isotopes are usually measured as the ratio between the heavier isotope $\left(\right.$ e.g. $\left.{ }^{15} \mathrm{~N}\right)$ and the lighter isotope $\left(\right.$ e.g. $\left.{ }^{14} \mathrm{~N}\right)$. These ratios are referenced to international standards using delta notation $(\delta)$, which is used to express the small variations in isotopic composition that occur and is defined by Eq. 4, where $R={ }^{15} \mathrm{~N} /{ }^{14} \mathrm{~N}$.

$$
\delta^{15} N=\left[\left(R_{\text {sample }}-R_{\text {std }}\right) / R_{\text {std }}\right] \times 1000
$$


1 The isotopic analyses included the $\delta^{15} \mathrm{~N}$ and $\delta^{18} \mathrm{O}$ of $\mathrm{NO}_{3}{ }^{-}, \delta^{15} \mathrm{~N}$ of $\mathrm{NH}_{4}{ }^{+}, \delta^{34} S$ and $\delta^{18} \mathrm{O}$ 2 of $\mathrm{SO}_{4}{ }^{2-}$. The $\delta^{15} \mathrm{~N}$ and $\delta^{18} \mathrm{O}$ of dissolved $\mathrm{NO}_{3}{ }^{-}$were determined using a modified 3 cadmium reduction method (Mcllvin and Altabet, 2005; Ryabenko et al., 2009). Briefly, $4 \mathrm{NO}_{3}{ }^{-}$was converted to $\mathrm{NO}_{2}{ }^{-}$through spongy cadmium reduction and then to nitrous oxide 5 using sodium azide in an acetic acid buffer. Simultaneous $\delta^{15} \mathrm{~N}$ and $\delta^{18} \mathrm{O}$ analysis of the

$6 \quad \mathrm{~N}_{2} \mathrm{O}$ produced was carried out using a Pre-Con (Thermo Scientific) coupled to a Finnigan 7 MAT-253 Isotope Ratio Mass Spectrometer (IRMS, Thermo Scientific). The $\delta^{15} \mathrm{~N}_{\text {of }} \mathrm{NH}_{4}{ }^{+}$ 8 was analysed by the $\mathrm{NH}_{4}{ }^{+}$diffusion method using a Carlo Erba Elemental Analyser (EA) coupled in a continuous flow to a Finnigan Delta C IRMS (Thermo Scientific). For $\delta^{34} \mathrm{~S}$ and $\delta^{18} \mathrm{O}$ analyses, dissolved $\mathrm{SO}_{4}{ }^{2-}$ was precipitated as $\mathrm{BaSO}_{4}$ by adding $\mathrm{BaCl}_{2} \cdot 2 \mathrm{H}_{2} \mathrm{O}$ after acidifying the sample with $\mathrm{HCl}$ and boiling it to prevent $\mathrm{BaCO}_{3}$ precipitation, following standard methods (Dogramaci et al., 2001). The $\delta^{34} S$ was also analysed with the Carlo Erba EA -Finnigan Delta C IRMS. The $\delta^{18} \mathrm{O}$ was analysed in duplicate using a ThermoQuest high temperature conversion elemental analyser (TC/EA) coupled in continuous flow with a Finnigan MAT Delta C IRMS. For $\delta^{13} \mathrm{C}_{\mathrm{DIC}}$, carbonates were converted to $\mathrm{CO}_{2}$ gas by adding a phosphoric acid solution and the isotope ratio was measured in a Gas-Bench II coupled to a MAT-253 IRMS (Thermo Scientific). The $\delta^{13} \mathrm{C}$ and $\delta^{15} \mathrm{~N}$, as well as total C (\%), of the two tested organic substrates were measured using the Carbo Erba EA-Finnigan Delta C IRMS. Isotope ratios were calculated using both international and internal laboratory standards. Notation was expressed in terms of $\delta$ relative to the international standards (V-SMOW for $\delta^{18} \mathrm{O}$, atmospheric $\mathrm{N}_{2}$ for $\delta^{15} \mathrm{~N}$ and V-CDT for $\delta^{34} S$ ). The reproducibility of the samples was $\pm 1 \%$ or the $\delta^{15} \mathrm{~N}$ of $\mathrm{NO}_{3}{ }^{-}, \pm 0.5 \%$ o for the $\delta^{15} \mathrm{~N}_{\text {of }} \mathrm{NH}_{4}{ }^{+}, \pm 1.5 \%$ or for the $\delta^{18} \mathrm{O}$ of $\mathrm{NO}_{3}{ }^{-}, \pm 0.2 \%$ for the $\delta^{34} \mathrm{~S}$ of $\mathrm{SO}_{4}{ }^{2-}$ and $\pm 0.5 \%$ o for the $\delta^{18} \mathrm{O}$ of $\mathrm{SO}_{4}{ }^{2}$. Samples for isotopic analyses were prepared at the "Mineralogia Aplicada I Geoquímica de Fluids" laboratory and determined at the "Centres Científics i Tecnològics" of the Universitat de Barcelona (CCiT-UB). 


\subsection{Isotope data evaluation}

2 Isotopic fractionation during denitrification can be expressed as a Rayleigh distillation

3 process (Eq. 5), from which the isotopic fractionation factor a can be obtained (Mariotti

4 et al., 1988; Aravena and Robertson, 1998).

$$
\operatorname{Ln}\left({ }^{R_{t}} / R_{0}\right)=(\alpha-1) * \operatorname{Ln}\left(C_{t} / C_{0}\right)
$$

6 where $\mathrm{C}_{0}$ and $\mathrm{C}_{t}$ are the initial and residual $\mathrm{NO}_{3}{ }^{-}$concentrations, respectively $\left(\mathrm{mmol} \mathrm{L}^{-1}\right)$,

7 and $R_{0}$ and $R_{t}$ denote the ratios of heavy versus light isotopes in the initial and residual

8 isotopic ratios, respectively, which are calculated according to Eq. 6 .

$$
R=[(\delta / 1000)+1]
$$

where $\delta$ is the isotopic composition of $\delta^{15} \mathrm{~N}$ and $\delta^{18} \mathrm{O}(\%)$. The term $(\alpha-1)$ was calculated from the slope of the regression analysis in double-logarithmic plots $\left[\ln \left(R_{t} / R_{0}\right)\right]$ over $\left[\ln \left(C_{t} / C_{0}\right)\right]$ according to Eq. 5 , and converted to isotopic fractionation ( $\varepsilon_{N}$ and $\left.\varepsilon_{0}\right)$ according to Eq. 7.

$$
\varepsilon=1000 \times(\alpha-1)
$$

The Rayleigh equation applies to closed system conditions; therefore, isotopic fractionation is commonly calculated in laboratory experiments where conditions are well constrained, no other sinks affect the $\mathrm{NO}_{3}{ }^{-}$pool and the concentration and isotopic composition of $\mathrm{NO}_{3}{ }^{-}$can be considered exclusively determined by $\mathrm{NO}_{3}{ }^{-}$reduction.

\section{Results}

Results of the batch experiments are detailed in supplementary material Table S1, and results of the flow through experiments are detailed in Tables S2-S5.

\subsection{Batch experiments: chemical data}

In the sterilised control (SCB) and absence control (ACB) experiments, $\mathrm{NO}_{3}^{-}$reduction did not occur. Results for CCB experiments showed complete $\mathrm{NO}_{3}{ }^{-}$consumption in less than 12 days (Fig. 1a). At $t=0$ (right after the groundwater spiked with NaNO3 was put in contact with the commercial compost) an initial NO3- release by the compost of up to 
$12.58 \mathrm{mM}$ was observed. In the palm tree batch experiment (PTB), complete $\mathrm{NO}_{3}{ }^{-}$

2 reduction was achieved in less than 20 hours with no significant initial $\mathrm{NO}_{3}{ }^{-}$release (Fig.

3 1b). In both batch experiments, transient $\mathrm{NO}_{2}{ }^{-}$accumulation was observed. In the $\mathrm{CCB}$

4 experiment, up to $0.1 \mathrm{mM}$ of $\mathrm{NO}_{2}^{-}$was released on the first day, and thereafter $\mathrm{NO}_{2}{ }^{-}$

5 concentration gradually decreased. In the PTB experiment, $\mathrm{NO}_{2}{ }^{-}$transient accumulation

6 was more significant, with a concentration peak of $0.7 \mathrm{mM}$ after 14 hours, which

7 corresponds to $81 \%$ of the initial $\mathrm{NO}_{3}{ }^{-}$concentration. $\mathrm{NO}_{2}{ }^{-}$content was negligible after 22

8 hours.

\subsection{Flow-through experiments: chemical data}

Results for the evolution of $\mathrm{NO}_{3}{ }^{-}, \mathrm{NO}_{2}^{-}, \mathrm{NH}_{4}{ }^{+}, \mathrm{SO}_{4}{ }^{2-}, \mathrm{NPDOC}$ and DIC during the flowthrough experiments are shown in Figures 2 (CCC) and 3 (PTC). The CCC experiment was characterised by a large initial $\mathrm{NO}_{3}{ }^{-}$release (up to $4.3 \mathrm{mM}$ ) in the first 4 days of stage I. This $\mathrm{NO}_{3}{ }^{-}$was released due to leaching from the compost, similarly to what was observed in the CCB experiment. After that, complete $\mathrm{NO}_{3}{ }^{-}$consumption was achieved. The decrease in $\mathrm{NO}_{3}{ }^{-}$concentration was coupled with a slight increase in $\mathrm{NO}_{2}^{-}$, which reached values of up to $1.3 \mathrm{mM}$ in the first 7 days. A slight $\mathrm{NH}_{4}{ }^{+}$concentration was detected in the output (values between $0.03 \mu \mathrm{M}$ and $0.4 \mathrm{mM}$, Fig. 4a). The $\mathrm{SO}_{4}{ }^{2-}$ concentration in the input water was $1.9 \mathrm{mM}$, and in the outflow water it ranged from 0.4 $\mathrm{mM}$ to $3.8 \mathrm{mM}$. For most of stage I, outflow $\mathrm{SO}_{4}{ }^{2-}$ concentrations were below inflow concentrations (Fig. 2). The concentration of NPDOC showed a sharp increase up to 38.4 $\mathrm{mM}$ during the first 4 days, followed by a rapid decrease to $0.1 \mathrm{mM}$ (Fig. 2). DIC content in the output samples was higher than in the inflow water throughout the experiment, ranging from $6.8 \mathrm{mM}$ to $8.9 \mathrm{mM}$ (Fig. 2).

After the 7 week lag period, no NO3- leaching from the compost was observed and NO3concentrations decreased progressively to values below the detection limit $(0.002 \mathrm{mM})$.

27 During this stage, no significant $\mathrm{NO}_{2}^{-}$accumulation was observed. The outflow concentration values for $\mathrm{NH}_{4}{ }^{+}$and NPDOC in stage II remained close to the detection 
1 limit $(0.03 \mu \mathrm{M}$ and $8 \mu \mathrm{M})$, and $\mathrm{SO}_{4}{ }^{2-}$ concentrations were below inflow concentrations by

2 the end of this stage (after 213 days).

3 In the PTC experiment, no significant initial $\mathrm{NO}_{3}{ }^{-}$and $\mathrm{NO}_{2}{ }^{-}$release was observed (Fig. 3).

4 In contrast to the CCC experiment, a sharp increase in $\mathrm{NH}_{4}{ }^{+}$(up to $6.3 \mathrm{mM}$ after 1 day)

5 was detected (Fig. 4b). Similarly to the CCC experiment, outflow $\mathrm{SO}_{4}{ }^{2-}$ concentrations

6 were below inflow concentrations for most of stage I. NPDOC concentrations remained

7 stable at between $0.1 \mathrm{mM}$ and $0.2 \mathrm{mM}$ and, in contrast to the $\mathrm{CCC}$ experiment, there

8 was no sharp increase at the beginning of the experiment (Fig. 3). Output DIC values

9 were lower than input values except on the first day (Fig. 3). After the lag period, complete denitrification was again achieved, although small $\mathrm{NO}_{3}^{-}$peaks were observed, probably due to flow rate changes. Similarly to the $\mathrm{CCC}$ experiment, no significant $\mathrm{NO}_{2}{ }^{-}$ or $\mathrm{NH}_{4}^{+}$accumulation was observed and outflow sulphate concentrations were below inflow concentrations by the end of stage II (after 173 days). The main difference was a significant initial NPDOC release (up to $2.5 \mathrm{mM}$ ).

\subsection{Isotopic results}

In the CCB experiment, an increase of both $\delta^{15} \mathrm{~N}-\mathrm{NO}_{3}{ }^{-}$(from $+9.4 \%$ to $+65.6 \%$ ) and $\delta^{18} \mathrm{O}$ $\mathrm{NO}_{3}^{-}$(from $+18.6 \%$ to $+52.6 \%$ ) was observed as the $\mathrm{NO}_{3}{ }^{-}$concentration decreased (Supplementary material, Table S1). In the PTB experiment, the $\delta^{15} \mathrm{~N}$ of dissolved $\mathrm{NO}_{3}{ }^{-}$ increased (from $+15.40 \%$ o to $+32.10 \%$ ) as the $\mathrm{NO}_{3}{ }^{-}$concentration decreased (Table S1). In the latter experiment, rapid $\mathrm{NO}_{3}{ }^{-}$consumption promoted considerable $\mathrm{NO}_{2}{ }^{-}$ accumulation, hindering the determination of $\delta^{18} \mathrm{O}_{\mathrm{NO}}$. A subset of 22 outflow samples from the CCC experiment and 14 samples from the PTC experiment was selected for $\mathrm{NO}_{3}{ }^{-}$and $\mathrm{NH}_{4}{ }^{+}$isotopic analyses. In the CCC experiment, the isotopic composition of dissolved $\mathrm{NO}_{3}{ }^{-}$showed an increase from $+15.0 \%$ o to $+61.3 \%$ of $\delta^{15} \mathrm{~N}$, and from $+10.6 \%$ 。 to $+52.2 \%$ or for $\delta^{18} \mathrm{O}$ during the first 10 days of stage I, coinciding with the complete consumption of $\mathrm{NO}_{3}{ }^{-}$(Supplementary material, Table S3) . In stage II, $\delta^{15} \mathrm{~N}$ and $\delta^{18} \mathrm{O}$ increased during the two periods of $\mathrm{NO}_{3}{ }^{-}$reduction (up to $+60.7 \%$ and $+49.8 \%$, 
1 respectively) (Table S3) separated by $\mathrm{a} \mathrm{NO}_{3}{ }^{-}$rebound linked to an increase in flow rate

2 up to $0.4 \mathrm{~mL} \mathrm{~min}-1$ (from 154 to 165 days). Stage II of the PTC experiment showed a

3 similar trend to that of the CCC experiment, whereby the isotopic composition of

4 dissolved $\mathrm{NO}_{3}{ }^{-}$showed an increase from $+16.5 \%$ o to $+53.2 \%$ for $\delta^{15} \mathrm{~N}$, and from $+21.4 \%$

5 to $+62.3 \%$ of $\delta^{18} \mathrm{O}$, coinciding with the complete consumption of $\mathrm{NO}_{3}{ }^{-}$(Supplementary

6 material, Table S5). The $\delta^{15} \mathrm{~N}$ values of dissolved $\mathrm{NH}_{4}{ }^{+}$ranged between $+7.1 \%$ and

$7+11.4 \%$ in the CCC experiment, whereas a wider range of values was observed in the

8 PTC experiment, from $+2.2 \%$ to $+17.9 \%$ (Fig. 4).

9 The $\delta^{13} C_{D I C}$ was determined in a subset of 28 samples from stage I of the CCC 10 experiment and 15 samples from both stages of the PTC experiment. The $\delta^{13} C_{D I C}$ values 11 ranged from $-13.2 \%$ o to $-18.6 \%$ for the CCC experiment and from $-10.3 \%$ o to $-18.0 \%$ 12 (stage I) and from $-16.0 \%$ o to $-16.9 \%$ o (stage II) for the PTC experiment. A subset of 25 samples from each experiment, with varying $\mathrm{SO}_{4}{ }^{2-}$ concentrations, was analysed to determine the isotopic composition of dissolved $\mathrm{SO}_{4}{ }^{2-}\left(\delta^{34} \mathrm{~S}_{\mathrm{SO}}\right.$ and $\left.\delta^{18} \mathrm{O}_{\mathrm{SO}}\right)$. In the CCC experiment, the outflow $\delta^{34} S$ and $\delta^{18} \mathrm{O}$ values ranged from $+7.7 \%$ o to $+22.4 \%$ and from $+10.1 \%$ to $+13.6 \%$, respectively (Supplementary material, Table S3). In the PTC experiment, values ranged from $+9.1 \%$ o to $+10.6 \%$ for $\delta^{34} S$, and from $+11.2 \%$ to $+11.1 \%$ o for $\delta^{18} \mathrm{O}$ (Supplementary material, Table S5)

\section{Discussion}

\subsection{Nitrogen - sulphate geochemistry and nitrate attenuation}

Complete $\mathrm{NO}_{3}{ }^{-}$attenuation was achieved in all the experiments. In the column experiments, the $\mathrm{CCC}$ experiment showed an initial $\mathrm{NO}_{3}{ }^{-}$release, a temporary $\mathrm{NO}_{2}{ }^{-}$ accumulation, and a slight $\mathrm{NH}_{4}{ }^{+}$increase, whereas in the PTC experiment very low $\mathrm{NO}_{2}{ }^{-}$ accumulation and a large initial $\mathrm{NH}_{4}{ }^{+}$increase was observed. This increase in $\mathrm{NH}_{4}{ }^{+}$might indicate $\mathrm{NH}_{4}^{+}$leaching from vegetal decomposition, but could also be generated by DNRA. If $\mathrm{NH}_{4}{ }^{+}$was leached from the organic substrates, its isotopic composition should 
1 be in agreement with the reactive material (compost/palm leaves). This was observed in

2 the CCC experiment and in the first days of the PTC experiment (Fig. 4). Therefore, it is

3 reasonable to assume that $\mathrm{NH}_{4}{ }^{+}$leaching was the main source of $\mathrm{NH}_{4}{ }^{+}$observed at the

4 beginning of both experiments. However, by the end of stage I of the PTC experiment,

$5 \quad \delta^{15} \mathrm{~N}_{\mathrm{NH} 4}$ values were significantly higher (up to $+16.2 \%$ ), a finding that could not be

6 explained by leaching. Instead, a feasible hypothesis is the occurrence of DNRA. In

7 general terms, DNRA is favoured under higher $\mathrm{C}$ to $\mathrm{NO}_{3}^{-}$ratios when the electron

8 acceptor $\left(\mathrm{NO}_{3}{ }^{-}\right)$becomes limiting and the system is rich in labile carbon (Korom et al.,

9 1992; Burgin and Hamilton, 2007). Accordingly, the highest $\mathrm{C} / \mathrm{N}$ ratio was observed in the stage I of the PTC experiment when $\mathrm{NH}_{4}{ }^{+}$isotope data discards $\mathrm{NH}_{4}{ }^{+}$leaching and points to the occurrence of DNRA. Nevertheless, DNRA can also occur under low C/N ratios (Carrey et al., 2014). In addition, it seems that the type of organic carbon may have some role in the development of denitrification or DNRA. Further research is needed to better understand which process is taking place. However, the extent of DNRA in the present experiments was limited, since even assuming that $\mathrm{NH}_{4}{ }^{+}$was derived from DNRA, this would only account for a maximum of $15 \%$ of $\mathrm{NO}_{3}{ }^{-}$attenuation in the PTC experiment. Therefore, the main $\mathrm{NO}_{3}{ }^{-}$attenuation process in both experiments was denitrification.

The $\mathrm{NO}_{3}{ }^{-}$reduction pathway depends on the biomass present in the system, which is controlled by the type of organic carbon available (Nijburg et al., 1998). In addition, Abell et al. (2009) have reported that DNRA bacteria have the capacity to use organic substrates unavailable to denitrifier bacteria. It is reasonable to assume that the differences observed in the two experiments with regard to $\mathrm{NH}_{4}{ }^{+}$generation could be explained by the different organic matter used as electron donor. Palm tree leaves have the capacity to release more $\mathrm{NH}_{4}{ }^{+}$than commercial compost, besides being a labile organic substrate that facilitates $\mathrm{NH}_{4}{ }^{+}$formation through the DNRA process. These results are consistent with the marked differences in NPDOC values obtained in the first sample of the batch experiments: $150 \mathrm{mg} \mathrm{L}^{-1}$ for the PTB and $4 \mathrm{mg} \mathrm{L}^{-1}$ for the CCB. 
1 After the lag period, in stage II of both experiments a faster denitrification was observed.

2 Therefore, it was demonstrated a high denitrification potential for these two types of 3 organic material ( $\mathrm{CC}$ and $\mathrm{PT})$. These substrates might be used in ARP, where the 4 conditions are variable; even during dry periods, when a potential entry of oxygen might 5 occur.

$6 \mathrm{SO}_{4}{ }^{2-}$ reduction may be promoted when $\mathrm{NO}_{3}{ }^{-}, \mathrm{Mn}$ and $\mathrm{Fe}$ have been entirely consumed 7 but organic carbon is still available. The input water contained Fe and Mn concentrations 8 below the detection limit ( $2 \mu \mathrm{M}$ and $0.2 \mu \mathrm{M}$, respectively); therefore, once the $\mathrm{NO}_{3}{ }^{-}$had 9 been completely consumed, $\mathrm{SO}_{4}{ }^{2-}$ reduction could occur according to the redox

27 sequence in natural systems, since most of the organic matter was still available for degradation. For most of stage I and by the end of stage II in both the CCC and PTC experiments, $\mathrm{SO}_{4}{ }^{2-}$ consumption was observed once all the $\mathrm{NO}_{3}{ }^{-}$had been removed. In addition, in both experiments, Eh was close to the values that have been reported to promote $\mathrm{SO}_{4}{ }^{2-}$ reduction (below $-150 \mathrm{mV}$, Connell and Patrick, 1968). Isotope results confirmed the occurrence of sulphate reduction (see Supporting material).

\subsection{Denitrification rate and organic $\mathrm{C}$ reactivity}

In order to quantitatively compare the reactivity of the two organic carbon sources, we developed a kinetic model of the two batch experiments. As the observed $\mathrm{NO}_{2}{ }^{-}$ concentration in the experiments was high (up to $33.4 \mathrm{mg} \mathrm{L}^{-1}$ ), the model considered two main processes: 1) the degradation of $\mathrm{NO}_{3}{ }^{-}$into $\mathrm{NO}_{2}{ }^{-}$, and 2) the degradation of $\mathrm{NO}_{2}{ }^{-}$ into $\mathrm{N}_{2}(\mathrm{~g})$. We tested different kinetics during the modelling process, and found that the best combination was zero order kinetics for the degradation of $\mathrm{NO}_{3}^{-}$into $\mathrm{NO}_{2}^{-}$(Eq. 8) and first order degradation considering inhibition by $\mathrm{NO}_{3}{ }^{-}$for the degradation of $\mathrm{NO}_{2}{ }^{-}$into $\mathrm{N}_{2}$ (g) (Eq. 9).

$$
r_{N O_{3}^{-}}=-K_{1}
$$

$$
r_{N O_{2}^{-}}=+Q K_{1}-K_{2}\left[N O_{2}^{-}\right]\left(K_{i} / K_{i}+\left[N O_{3}^{-}\right]\right)
$$


1 where $r$ is the degradation rate of $\mathrm{NO}_{3}^{-}$and $\mathrm{NO}_{2}^{-}\left[\mathrm{ML}^{-3} \mathrm{~T}^{-1}\right], \mathrm{K}_{1}$ is the zero degradation

2 constant $\left[\mathrm{ML}^{-3} \mathrm{~T}^{-1}\right], \mathrm{Q}$ is the stoichiometric ratio between $\mathrm{NO}_{3}{ }^{-}$and $\mathrm{NO}_{2}^{-}{ }^{-}$(1) $[-], \mathrm{K}_{2}$ is the

3 first order degradation rate $\left[\mathrm{T}^{-1}\right]$, and $\mathrm{K}_{\mathrm{i}}$ is the inhibition parameter $\left[\mathrm{ML}^{-3}\right]$. These results

4 contrast with those reported in previous studies, where the model that fit best was the

5 Monod kinetic model (e.g. Rodriguez-Escales et al., 2014; Carrey et al., 2014a). Zero

6 order kinetics is achieved when the substrate is not limiting. In this case, we supposed

7 that organic carbon was not limiting. Note that the amount of organic carbon in the

8 system was much higher than the amount of NO3- (Table 1 and 3). However, the

9 degradation of $\mathrm{NO}_{2}^{-}$into $\mathrm{N}_{2}(\mathrm{~g})$ was limited by the presence of $\mathrm{NO}_{2}^{-}$(first order kinetics

with respect to $\mathrm{NO}_{2}{ }^{-}$). Both rates were solved numerically considering a time step of 0.5

$d$ in the CCB experiment and $0.01 \mathrm{~d}$ in the case of PTB. Figure 5 gives the results of the model considering the parameters listed in Table 3 and an initial concentration of $\mathrm{NO}_{3}{ }^{-}$ of $2.49 \mathrm{mM}$ for $\mathrm{CCB}$ and $0.86 \mathrm{mM}$ for PTB. The initial concentrations were based on the initial measurements of the $\mathrm{NO}_{3}{ }^{-}$in the batch experiments (see Table S1). Note that the initial $\mathrm{NO}_{3}{ }^{-}$concentration in the $\mathrm{CCB}$ experiment was higher due to the fast leaching of $\mathrm{NO}_{3}{ }^{-}$from the compost. Regarding the parameters, it can be observed that the $\mathrm{K}_{1}$ value was 10 times higher in the PTB experiment than in the CCB experiment (Table 3), resulting in a characteristic time (i.e. the inverse of the reaction rate constant) of 0.5 days for PTB compared to 3.7 days for CCB. As $\mathrm{NO}_{2}^{-}$production in the PTB experiment was much faster than in the $\mathrm{CCB}$ one, and $\mathrm{NO}_{2}{ }^{-}$degradation rates were relatively similar in both experiments, higher $\mathrm{NO}_{2}^{-}$accumulation was expected in the PTB experiment (Fig. 5). Kinetic analysis of the column experiments was based on a $\mathrm{N}$ input-output mass balance. The $\mathrm{NO}_{3}{ }^{-}$concentration in the inflow water (plus $\mathrm{NO}_{3}{ }^{-}$nitrate initially leached from the compost and $\mathrm{NH}_{4}{ }^{+}$initially leached from the palm tree leaves) was considered as the input of the system, while outflow concentrations of $\mathrm{NO}_{3}{ }^{-}, \mathrm{NO}_{2}{ }^{-}$and $\mathrm{NH}_{4}{ }^{+}$were considered as the output. Any gaseous species such as $\mathrm{N}_{2} \mathrm{O}$ or $\mathrm{N}_{2}$ were not considered because they were not measured. The percentage of $\mathrm{N}$ consumption was calculated for each stage of both column experiments as the difference between the input and the 
1 output $\mathrm{N}$ masses in the system (Supplementary material, Table S6). During stage I,

2 higher $\mathrm{N}$ consumption was achieved with the palm tree leaves than with the compost,

3 although similar $\mathrm{N}$ consumption percentages were obtained in both cases after the lag

4 period.

5 Total $\mathrm{NO}_{3}{ }^{-}$removed during the experiments was $83.7 \mathrm{mmol}$ for the $\mathrm{CCC}$ experiment and

$6139.7 \mathrm{mmol}$ for the PTC experiment, respectively (Table S6). The stoichiometric amount

7 of $\mathrm{C}$ needed for the observed $\mathrm{NO}_{3}{ }^{-}$and $\mathrm{SO}_{4}{ }^{2-}$ depletion were calculated according to the

8 denitrification reaction (Eq.2), the DNRA reaction (Eq.10) and the sulphate reduction

9 reaction (Eq.11), respectively.

$$
\left(\mathrm{NO}_{3}^{-}+2 \mathrm{CH}_{2} \mathrm{O}+2 \mathrm{H}^{+} \rightarrow \mathrm{NH}_{4}^{+}+2 \mathrm{CO}_{2}+\mathrm{H}_{2} \mathrm{O}\right)
$$

$$
\left(\mathrm{SO}_{4}^{2-}+2 \mathrm{CH}_{2} \mathrm{O}+\mathrm{H}^{+} \rightarrow \mathrm{HS}^{-}+2 \mathrm{CO}_{2}+2 \mathrm{H}_{2} \mathrm{O}\right)
$$

Obtained values (125.3 mmols C for CCC and 194.8 mmols C for PTC) corresponded to $0.8 \%$ and $3.7 \%$ of the total $\mathrm{C}$ in both substrates. Degradable organic $\mathrm{C}$, including the organic carbon leached from the substrates, corresponded to $2.4 \%$ and $4.2 \%$ of the total C present in the commercial compost and palm tree leaves, respectively. Similar reactive organic $\mathrm{C}$ percentages have been obtained in other column experiments using fresh or old organic matter (between 2\% and 6\%, Abell et al., 2009; Carrey et al., 2013).

Palm tree leaves gave a higher denitrification yield (i.e. amount of $\mathrm{NO}_{3}$-nitrate consumed per amount of available $\mathrm{C})$ than $\mathrm{CC}\left(6\right.$ versus $\left.33 \mathrm{mmol} \mathrm{NO}_{3}{ }^{-} / \mathrm{mol} \mathrm{C}_{\text {org }}\right)$, probably because the organic carbon was easily degradable by the bacteria present in the water, enabling them to grow rapidly and produce complete $\mathrm{NO}_{3}{ }^{-}$attenuation in a short period of time.

\subsection{Nitrate isotope fractionation}

In the $\mathrm{CCB}$ and $\mathrm{CCC}$ experiments, denitrification was the only process consuming $\mathrm{NO}_{3}{ }^{-}$

25 . In order to calculate the $\varepsilon_{N}$ and $\varepsilon_{O}$ values, all the samples from both batch and column experiments were plotted together due to the similar trends observed. Figure 6 shows

27 the Rayleigh model for CCC and CCB. Using Eq. 9, isotopic fractionations were 
1 calculated as $-10.8 \%$ for $\varepsilon_{N}$ and $-9.0 \%$ for $\varepsilon_{0}$, with a $\varepsilon_{N} / \varepsilon_{O}$ of 1.2 . Due to the fast rate of

$2 \mathrm{NO}_{3}{ }^{-}$consumption and the transient $\mathrm{NO}_{2}{ }^{-}$accumulation in the experiments with palm tree

3 leaves, it was not possible to calculate isotopic fractionation in the batch experiments:

4 calculations were therefore based only on the PTC experiment. Furthermore, as DNRA

5 was detected, the isotopic fractionation obtained was an estimation of the isotope ratio

6 changes for both competing processes. The values obtained were $\varepsilon_{N}=-9.9 \%$ and $\varepsilon_{0}=-$

$78.6 \%$ with a $\varepsilon_{N} / \varepsilon_{O}$ of 1.15 (Figure 6 ).

8 The $\varepsilon_{N}$ and $\varepsilon_{0}$ values obtained were almost equal when using compost or palm tree

9 leaves as substrates, despite the different $\mathrm{NO}_{3}{ }^{-}$reduction rate and the limited contribution of DNRA in the PTC. With high denitrification rates, some authors have observed lower isotopic fractionation (Mariotti et al., 1988) whereas others have reported higher fractionation (Korom et al., 2012). In the present study, isotopic fractionation did not show any effect related to changes in the attenuation rate, in agreement with previous laboratory experiments (Carrey et al., 2014b). An overview of isotopic fractionation estimated from several laboratory studies is presented in Table 4.

The $\varepsilon_{N}$ and $\varepsilon_{O}$ values obtained in the present study fell within the range of values reported in the literature. The $\varepsilon_{N}$ values obtained were at the lower end of induced denitrification experiment values (Knöller et al., 2011; Carrey et al., 2014b). In general, autotrophic denitrification or pure culture experiments have obtained higher $\varepsilon_{N}$ values (in absolute terms) (Table 4). With regard to $\varepsilon_{0}$, some authors have reported an inverse fractionation $\left(\varepsilon_{0}>0 \%\right.$ ) due to ${ }^{16} \mathrm{O}$ loss during reduction of $\mathrm{NO}_{3}{ }^{-}$to $\mathrm{N}_{2} \mathrm{O}$ (Casciotti et al., 2002; Toyoda et al., 2005). The $\varepsilon_{0}$ calculated in the present study showed normal fractionation within the range of reported values for heterotrophic denitrification.

Recent studies have focused on the $\varepsilon_{N} / \varepsilon_{O}$ ratio in order to elucidate different processes affecting isotopic fractionation during $\mathrm{NO}_{3}{ }^{-}$reduction (Granger et al., 2008; Knöller et al., 2011). Factors such as $\mathrm{pH}$, salinity or carbon sources have been reported to show no effect on the $\varepsilon_{N} / \varepsilon_{0}$ ratio (Granger et al., 2008; Wunderlich et al., 2012). The incorporation of oxygen isotopes from water into $\mathrm{NO}_{3}{ }^{-}$and $\mathrm{NO}_{2}{ }^{-}$and re-oxidation of $\mathrm{NO}_{2}{ }^{-}$to $\mathrm{NO}_{3}{ }^{-}$have 
1 been observed to modify $\varepsilon_{0}$ in field studies. These processes tend to reduce $\varepsilon_{0}$ values,

2 increasing the $\varepsilon_{N} / \varepsilon_{0}$ ratio up to $1.8-2.0$. In denitrification laboratory experiments, a wider

3 range has been observed, from 0.96 (Carrey et al., 2013) to 2.9 (Knöller et al., 2011).

4 Higher values can be achieved when important $\mathrm{NO}_{2}^{-}$accumulation and $\mathrm{NO}_{2}{ }^{-}$re-oxidation

5 is produced (Knöller et al., 2011). The $\varepsilon_{N} / \varepsilon_{O}$ ratios obtained in the present experiments

6 were of 1.12 for $\mathrm{CCB}-\mathrm{CCC}$ and 1.15 for PTC. As palm and compost experiments were

7 performed under anaerobic conditions and $\mathrm{NO}_{2}{ }^{-}$accumulation only lasted for a few days,

8 re-oxidation of $\mathrm{NO}_{2}^{-}$can be ruled out. In addition, due to rapid $\mathrm{NO}_{3}^{-}$reduction and the

9 high isotopic composition of $\delta^{18} \mathrm{O}_{\mathrm{NO}}$ (up to $+62.3 \%$ ), the equilibrium isotope fractionation between water and $\mathrm{NO}_{3}{ }^{-}$can be considered negligible compared to kinetic isotope fractionation during $\mathrm{NO}_{3}^{-}$reduction.

12 Composition of the microbial community can also affect the $\varepsilon_{N} / \varepsilon_{0}$ ratio during denitrification (Dähnke and Thamdrup, 2016). Deviations in $\varepsilon_{N} / \varepsilon_{O}$ ratios can be produced

14 by different enzymes involved in $\mathrm{NO}_{3}{ }^{-}$reduction (Granger et al., 2008). Activity of the periplasmic $\mathrm{NO}_{3}{ }^{-}$reductase (Nap) in denitrifying bacteria resulted in a $\varepsilon_{N} / \varepsilon_{0}$ value of $\sim 1.6$ (Granger et al., 2008). However, membrane-bound respiratory $\mathrm{NO}_{3}{ }^{-}$reductase (Nar) is more common in classical heterotrophic denitrification and tends to produce $\varepsilon_{N} / \varepsilon_{0}$ values of $\sim 1.0$ (Granger et al., 2008). The $\varepsilon_{N} / \varepsilon_{O}$ ratios obtained in the present experiments were close to 1.0 , suggesting a lower influence of periplasmic $\mathrm{NO}_{3}{ }^{-}$reductase, in agreement with $\mathrm{NO}_{3}{ }^{-}$reduction driven by heterotrophic denitrification. As some DNRA was observed in the palm experiment, a higher $\varepsilon_{N} / \varepsilon_{0}$ would be expected, since the reduction of $\mathrm{NO}_{3}{ }^{-}$to $\mathrm{NO}_{2}^{-}$by DNRA is considered to be mainly catalysed by Nap complex (Kraft et al., 2011). However, the $\varepsilon_{N} / \varepsilon_{O}$ observed in PTC was 1.15 , similar to compost (1.12), in agreement with the main role of heterotrophic denitrification in $\mathrm{NO}_{3}{ }^{-}$attenuation. Likewise, the $\varepsilon_{N} / \varepsilon_{0}$ ratio in both experiments was close to values obtained in other laboratory experiments involving induced or natural denitrification in freshwater (Granger et al., 2008; Carrey et al., 2013; Carrey et al., 2014b). The published results suggest that denitrification produces ratios of around 1.0 and any deviation can be related to equilibrium isotope 
1 fractionation, re-oxidation of $\mathrm{NO}_{2}^{-}$or a different biological pathway of $\mathrm{NO}_{3}^{-}$reduction.

2 Induced denitrification at field scale may be masked by several processes, such as

3 dispersion, diffusion or dilution (mixing) that could change the $\mathrm{NO}_{3}{ }^{-}$concentration in

4 groundwater. The isotopic fractionation of $\mathrm{N}$ and $\mathrm{O}$ for dissolved $\mathrm{NO}_{3}^{-}$obtained in lab-

5 scale experiments may be used in future studies to assess system behaviour in the field

6 and optimise full-scale application.

\section{5. Conclusions}

8 This study shows that CC and PT have a satisfactory capacity to promote complete 9 denitrification, even after a lag stage without flow, simulating a dry period. However, a potential drawback in the use of these substrates is the initial $\mathrm{NH}_{4}{ }^{+}$release and the slight

$11 \mathrm{NO}_{2}-$ accumulation observed suggesting the necessity of a pre-treatment of the material 12 previously to be installed in the MAR system. Overall, the PT gave higher denitrification rate and yield making it suitable for MAR systems in arid and semi-arid climates, where

14 short-term efficient organic substrate is required.

15 Acknowledgements

16 This study was financed through the following projects: REMEDIATION (Spanish

17 Government, ref. CGL2014-57215-C4-1-R), MAG (Catalan Government, ref: 2014SGR18 1456) and WADIS-MAR (Water harvesting and Agricultural techniques in Dry lands: an 19 Integrated and Sustainable model in Maghreb Regions, European Commission, ref: ENPI/2011/280-008).

\section{References}

Abell, J., Laverman, A.M., Van Cappellen, P., 2009. Bioavailability of organic matter in a 23 freshwater estuarine sediment: long-term degradation experiments with and without 24 nitrate supply. Biogeochemistry 94, 13-28. Aravena, R., Robertson, W.D., 1998. Use of multiple isotope tracers to evaluate 26 denitrification in ground water: Study of nitrate from a large-flux septic system plume. 27 Ground Water 36, 975-982. 
1 Barford, C.C., Montoya, J.P., Altabet, M.A., Mitchell, R., 1999. Steady-state nitrogen

2 isotope effects of $\mathrm{N}_{2}$ and $\mathrm{N}_{2} \mathrm{O}$ production in Paracoccusdenitrificans. Appl. Environ.

3 Microb. 65, 989-994.

4 Bekele, E., Toze, S., Patterson, B., Higginson, S., 2011 Managed aquifer recharge of 5 treated wastewater: Water quality changes resulting from infiltration through the vadose 6 zone. Water Res., 45, 5764-5772.

7 Bouwer, H., 2002. Artificial recharge of groundwater: hydrogeology and engineering. 8 Hydrogeol. J. 10, 121-142.

9 Burgin, A.J., Hamilton, S.K., 2007. Have we overemphasized the role of denitrification in 10 aquatic ecosystems. A review of nitrate removal pathways. Front. Ecol. Environ. 5, 891196.

12 Carrey, R., Otero, N., Soler, A., Gomez-Alday, J.J., Ayora, C., 2013. The role of Lower 13 Cretaceous sediments in groundwater nitrate attenuation in central Spain: Column 14 experiments. Appl. Geochem. 32, 142-152.

15 Carrey, R., Otero, N., Vidal-Gavilan, G., Ayora, C., Soler, A., Gómez-Alday, J.J., 2014a. 16 Induced nitrate attenuation by glucose in groundwater: Flow-through experiment. Chem. 17 Geol. 370, 19-28.

18 Carrey, R., Rodríguez-Escales, P., Otero, N., Ayora, C., Soler, A., Gómez-Alday, J.J., 19 2014b. Nitrate attenuation potential of hypersaline lake sediments in central Spain: Flowthrough and batch experiments. J. Contam. Hydrol. 164, 323-337.

Casciotti, K.L., Sigman, D.M., Hastings, M.G., Böhlke, J.K., Hilkert, A., 2002. Measurements of the oxygen isotopic composition of nitrate in seawater and freshwater using the denitrifier method. Anal.Chem. 74, 4905-4912.

Connell, W.E., Patrick jr. W.H., 1968. Sulfate reduction in soil: effects of redox potential and $\mathrm{pH}$. Science 159, 86-87. anammox and denitrification in marine sediments. Limnol. Oceanogr. 61, 610-624. 
1 DeBeer, D., Schramm, A., Santegoeds, C.M., Kuhl, M., 1997. A nitrite microsensor for

2 profiling environmental biofilms. Appl. Environ. Microbiol. 63, 973-977.

3 Díaz-Cruz, M., Barceló, D., 2008. Trace organic chemicals contamination in ground 4 water recharge. Chemosphere, 72, 333-342.

5 Directive 98/83/EC. Council Directive 98/83/EC of the European Parliament of the 3 6 November 1998 on the quality of water intended for human consumption. Off. J. Eur. 7 Communities L 330, of 5.12.1998, 32-54.

8 Delwiche, C.C., Steyn, P.L., 1970. Nitrogen isotope fractionation in soils and microbial 9 reactions. Environ. Sci. Technol. 4, 929-935.

10 Dogramaci, S.S., Herczeg, A.L., Schi, S.L., Bone, Y., 2001. Controls on $\delta^{34} S$ and $\delta^{18} O$ 11 of dissolved sulfate in aquifers of the Murray Basin, Australia and their use as indicators of flow processes. Appl. Geochem. 16, 475-488.

Ghiglieri, G., Baba Sy, M.O., Yahyaou, H., Ouessar, M., Ouldamara, A., Soler, A., Arras, C., Barbieri, M., Belkheiri, O., Zaied, M.B., Buttau, C., Carletti, A., Da Pelo, S., Dodo, A., 15 Funedda, A., Iocola, I., Meftah, E., Mokh, F., Nagaz, K., Melis, M.T., Pittalis, D., Said, M., Sghaier, M., Torrentó, C., Virdis, S., Zahrouna, A., Enne, G., 2014. Design of Artificial Aquifer Recharge Systems in semi-arid regions of Maghreb (North Africa). Flowpath National Meeting on Hydrogeology. Viterbo. Abstract Volume: 144-145. ISBN 978-88907553-4-7.

Gibert, O., Pomierny, S., Rowe, I., Kalin, R.M., 2008. Selection of organic substrates as potential reactive materials for use in a denitrification permeable reactive barrier (PRB). Bioresources Technol. 99, 7587-7596.

Granger, J., Sigman, D.M., Lehmann, M.F., Tortell, P.D., 2008. Nitrogen and oxygen 24 isotope fractionation during dissimilatory nitrate reduction by denitrifying bacteria. 25 Limnol. Oceanogr. 53, 2533-2545.

26 Grischek, T., Hiscock, K.M., Metschies, T., Dennis, P.F., Nestler, W., 1998. Factors 27 affecting denitrification during infiltration of river water into a sand and gravel aquifer in 28 Saxony, Germany. Water Res.32, 450-460 
1 Hosono, T., Alvarez, K., L., Lin, I.T., Shimada, J., 2015. Nitrogen, carbon, and sulfur

2 isotopic change during heterotrophic (Pseudomonas aureofaciens) and autotrophic

3 (Thiobacillus denitrificans) denitrification reactions. J. Contam. Hydrol. 183, 72-81.

4 Knöller, K., Vogt, C., Haupt, M., Feisthauer, S., Richnow, H.H., 2011. Experimental 5 investigation of nitrogen and oxygen isotope fractionation in nitrate and nitrite during 6 denitrification. Biogeochemistry 103, 371-384.

7 Knowles, R., 1982. Denitrification. Microbiol. Rev. 46, 43-70.

8 Korom, S.F., 1992. Natural denitrification in the saturated zone - A review. Water 9 Resour. Research 28, 1657-1668.

Korom, S.F., Schuh, W.M., Tesfay, T., Spencer, E.J., 2012. Aquifer denitrification and in situ mesocosms: Modeling electron donor contributions and measuring rates. J. Hydrol. 432-433, 112-126.

Kraft, B., Strous, M., Tegetmeyer, H.E., 2011. Microbial nitrate respiration - Genes, enzymes and environmental distribution. J. Biotechnol. 155, 104-117.

Kuster, M.; Díaz-Cruz, S.; Rosell, M.; López de Alda, M.; Damià Barceló, D., 2010. Fate of selected pesticides, estrogens, progestogens and volatile organic compounds during artificial aquifer recharge using surface waters. Chemosphere, 79, 880-886.

Leverenz, H.L., Haunschild, K., Hopes, G., Tchobanoglous, G., Darby, J.L., 2010. Anoxic treatment wetlands for denitrification. Ecol. Eng. 36, 1544-1551.

Maeng, S.K., Sharma, S.J., Lekkerkerker-Teunissen, K., Amy, G.L., 2011. Occurrence and fate of bulk organic matter and pharmaceutically active compounds in managed aquifer recharge: A review. Water Res., 45, 3015-3033.

Magee, P.N., Barnes, J.M., 1956. The production of malignant primary hepatic tumours in the rat by feeding dimethylnitrosamine. Br. J. Cancer. 10, 114.

Mariotti, A., Landreau, A., Simon, B., 1988. 15N isotope biogeochemistry and natural denitrification process in groundwater application to the chalk aquifer of northern France. Geochim. Cosmochim. Acta 52, 1869-1878. 
1 Mcllvin, M.R., Altabet, M.A., 2005. Chemical conversion of nitrate and nitrite to nitrous

2 oxide for nitrogen and oxygen isotopic analysis in freshwater and seawater. Anal. Chem.

$3 \quad 77,5589-5595$.

4 Miller, J.H., Ela, W.P., Lansey, K.E., Chipello, P.L., Arnold, R.G., 2006. Nitrogen

5 transformations during soil-aquifer treatment of wastewater effluent - Oxygen effects in

6 field studies. J. Environ. Eng.-Asce, 132, 1298-1306.

7 Nijburg, J.W., Gerards, S., Laanbroek, H.J., 1998. Competition for nitrate and glucose 8 between Pseudomonas fluorescens and Bacillus licheniformis under continuous or 9 fluctuating anoxic conditions. FEMS Microb. Ecol. 26, 345-356.

10 Pehlivanoglu-Mantas, E., Sedlak, D.L., 2008. Measurement of dissolved organic 11 nitrogen forms in wastewater effluents: Concentrations, size distribution and NDMA 12 formation potential. Water Res., 42, 3890-3898.

Robertson, W.D., Vogan, J.L., Lombardo, P.S., 2008. Nitrate removal rates in a 15-year14 old permeable reactive barrier treating septic system nitrate. Ground Water Monit. R. 28, $15 \quad 65-72$.

Rodríguez-Escales, P., van Breukelen, B.M., Vidal-Gavilan, G., Soler, A., Folch, A., 17 2014. Integrated modelling of biogeochemical reactions and associated isotope fractionations at batch scale: A tool to monitor enhanced biodenitrification applications. Chem. Geol. 365, 20-29.

Ryabenko, E., Altabet, M.A., Wallace, D.W.R., 2009. Effect of chloride on the chemical conversion of nitrate to nitrous oxide for $\delta 15 \mathrm{~N}$ analysis. Limnol. Oceanogr. 7, 545-552.

Soler, A., Torrentó, C., Barbieri, M., Canals, A., Otero, N., Domènech, C., Carrey, R., Audí-Miró, C., Puig, R., Navarro-Ciurana, D., Rodríguez-Fernández, D., Grau-Martínez, A., de Olamendi, M., Marimón, R.M., Rodríguez, D., 2016. Hydrochemical and Isotopical characterization of the Oued Biskra watershed (Algeria). WADIS-MAR Final conference International Workshop on sustainable water resources management in arid and semiarid Regions. Available on line at: www.wadismar.eu/images/poster/2.pdf

Spalding, R.F., Exner, M.E., 1993. Occurrence of nitrate in groundwater - A review. J.

Environ. Qual. 22, 392-402. 
1 Sutka, R.L., Ostrom, N.E., Breznak, P.H., Gandhi, H., Pitt, A.J., Li, F., 2006.

2 Distinguishing nitrous oxide production from nitrification and denitrification on the basis

3 of isotopomer abundances. Appl. Environ. Microbiol. 72, 638-644.

4 Tiedje, J.M., Sexstone, A.J., Myrold, D.D., Robinson, J.A., 1982. Denitrification:

5 ecological niches, competition and survival. Ant. Van Leeuw. J. Micros, 48, 569-583.

6 Torrentó, C., Cama, J., Urmeneta, J., Otero, N., Soler, A., 2010. Denitrification of

7 groundwater with pyrite and Thiobacillus denitrificans. Chem. Geol. 278, 80-91.

8 Torrentó, C., Urmeneta, J., Otero, N., Soler, A., Viñas, M., Cama, J., 2011. Enhanced 9 denitrification in groundwater and sediments from a nitrate-contaminated aquifer after 10 addition of pyrite. Chem. Geol. 287, 90-101.

11 Toyoda, S., Mutobe, H., Yamagishi, H., Yoshida, N., Tanji, Y., 2005. Fractionation of N2O isotopomers during production by denitrifier. Soil Biol. Biochem. 37, 1535-1545.

13 Tsushima, K., Ueda, S., Ohno H., Ogura, N., Katase, T., Watanabe, K., 2006. Nitrate 14 decrease with isotopic fractionation in riverside sediment column during infiltration 15 experiment. Water Air Soil Pollut. 174, 47-61.

16 Valhondo, C., Carrera, J., Ayora, C., Barbieri, M., Noedler, K., Licha, T., Huerta, M., 17 2014. Behavior of nine selected emerging trace organic contaminants in an artificial 18 recharge system supplemented with a reactive barrier. Environ. Sci. Pollut. R. 21, 118321911843.

Vidal-Gavilan, G., Folch, A., Otero, N., Solanas, A.M., Soler, A., 2013. Isotope characterization of an in situ biodenitrification pilot-test in a fractured aquifer. Appl. Geochem. 32, 153-163.

Vidal-Gavilan, G., Carrey, R., Solanas, A., Soler, A., 2014. Feeding strategies for groundwater enhanced biodenitrification in an alluvial aquifer: Chemical, microbial and isotope assessment of a 1D flow-through experiment. Sci. Total Environ. 494-495, 241251.

27 Wellman, R.P., Cook, F.D., Krouse, H.R., 1968. Nitrogen-15 - microbiological alteration 28 of abundance. Science 161, 269-270. 
1 Westgate, P.J., Park, C., 2010. Evaluation of proteins and organic nitrogen in wastewater

2 treatment effluents. Environ. Sci. Technol., 44, 5352-5357.

3 Wunderlich, A., Meckenstock, R., Einsiedl, F., 2012. Effect of different carbon substrates

4 on nitrate stable isotope fractionation during microbial denitrification. Environ. Sci.

5 Technol. 46, 4861-4868.

6

\section{$9 \quad$ Figure captions}

10 Figure 1. Variation in $\mathrm{NO}_{3}{ }^{-}$and $\mathrm{NO}_{2}{ }^{-}$concentrations over time in the batch experiments.

(a) CCB and ACB experiments. (b) PTB and SCB experiments. Values and error bars represent the mean and standard deviation, respectively, for the three replicate experiments. Input- $\mathrm{NO}_{3}{ }^{-}$concentration is also shown.

14 Figure 2. Changes in $\mathrm{NO}_{3}^{-}, \mathrm{NO}_{2}^{-}, \mathrm{NH}_{4}^{+}, \mathrm{SO}_{4}{ }^{2-}, \mathrm{DIC}$ and NPDOC outflow concentrations over time under variable operating conditions for the $\mathrm{CCC}$ experiment. $\mathrm{NO}_{3}{ }^{-}, \mathrm{SO}_{4}{ }^{2}$ and DIC content of the inflow water are also shown (continuous and dashed lines, respectively). Content of NPDOC in the input water was low $\left(0,1 \mathrm{mgL}^{-1}\right)$.

Figure 3. Changes in $\mathrm{NO}_{3}{ }^{-}, \mathrm{NO}_{2}{ }^{-}, \mathrm{NH}_{4}{ }^{+}, \mathrm{SO}_{4}{ }^{2-}$, DIC and NPDOC outflow concentrations over time under variable operating conditions for the PTC experiment. $\mathrm{NO}_{3}{ }^{-}, \mathrm{SO}_{4}{ }^{2-}$ and DIC content of the inflow water are also shown (continuous and dashed lines, respectively). Content of NPDOC in the input water was low $\left(0,1 \mathrm{mgL}^{-1}\right)$.

Figure 4. Changes in $\mathrm{NH}_{4}{ }^{+}$concentration and isotopic composition over time in the outflow of both column experiments. (a) CCC and (b) PTC experiments. In both experiments, dashed lines represent the range of measured values of the $\delta^{15} \mathrm{~N}$ for each material 
1 Figure 5. Results of the model for the (a) CCB experiment and the (b) PTB experiment.

2 Open symbols represent experiment results, whereas dashed and continuous lines

3 represent model results

4 Figure 6. (a) and (c) $\delta^{15} \mathrm{~N}$ and (b) and (d) $\delta^{18} \mathrm{O}$ of $\mathrm{NO}_{3}{ }^{-}$against the natural logarithm of 5 the $\mathrm{NO}_{3}{ }^{-}$concentration of CCB-CCC (upper panels) and PTC (lower panels). Slopes of 6 the regression lines represent ( $\alpha-1)$, the isotopic fractionation factor for $\mathrm{N}$ and $\mathrm{O}$.

7

\section{Table captions}

9 Table 1. Summary of key parameters of both organic substrates used in the present experiments: CC and PT

11 Table 2. Experimental conditions of the batch experiments.

12 Table 3. Kinetic parameters used for modelling batch experiments.

13 Table 4. Estimated isotopic enrichment factor $(\varepsilon N$ and $\varepsilon O)$ obtained in this study and 14 reported in the literature for in situ natural denitrification in laboratory experiments. 
Figure 1
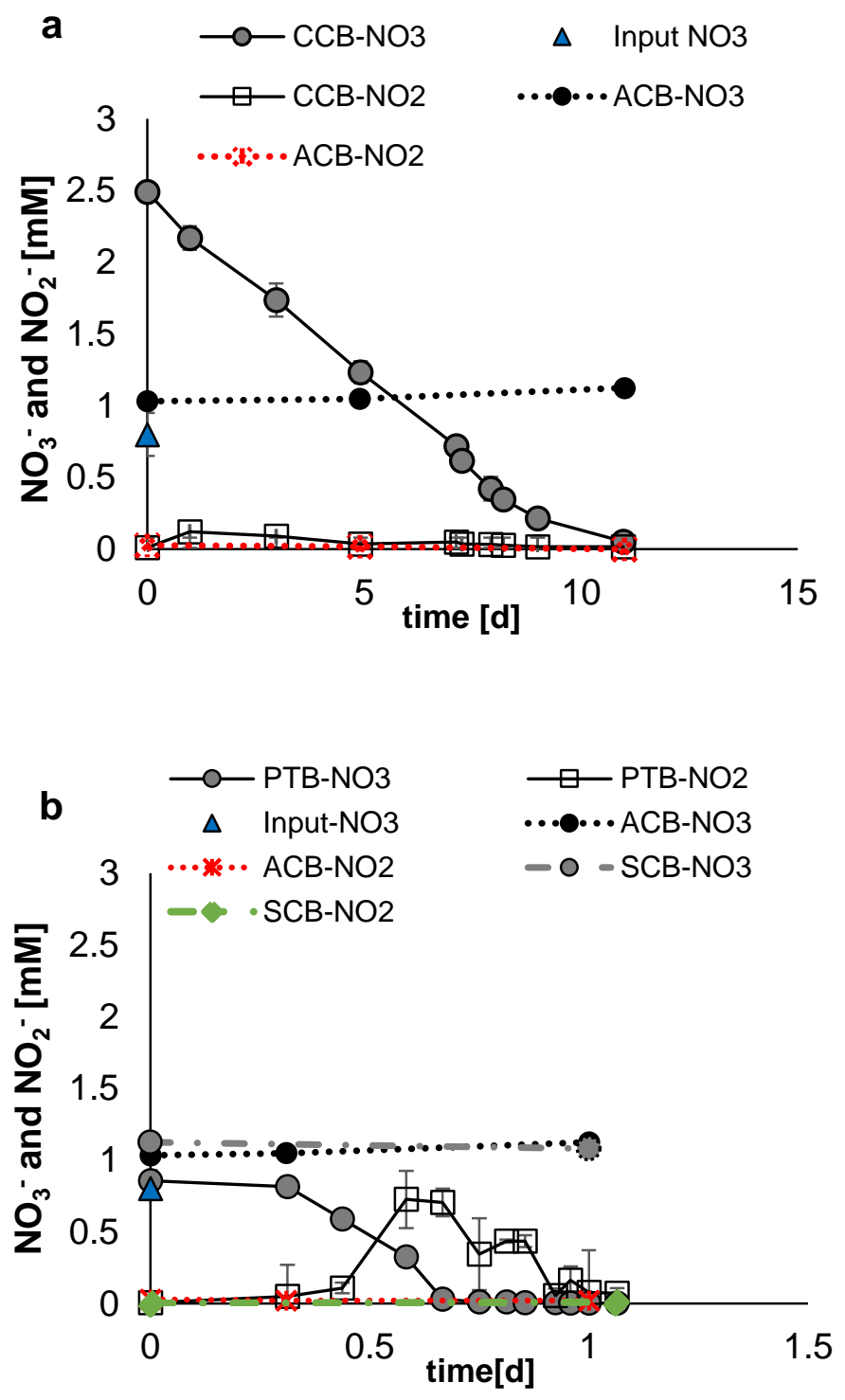
Figure 2

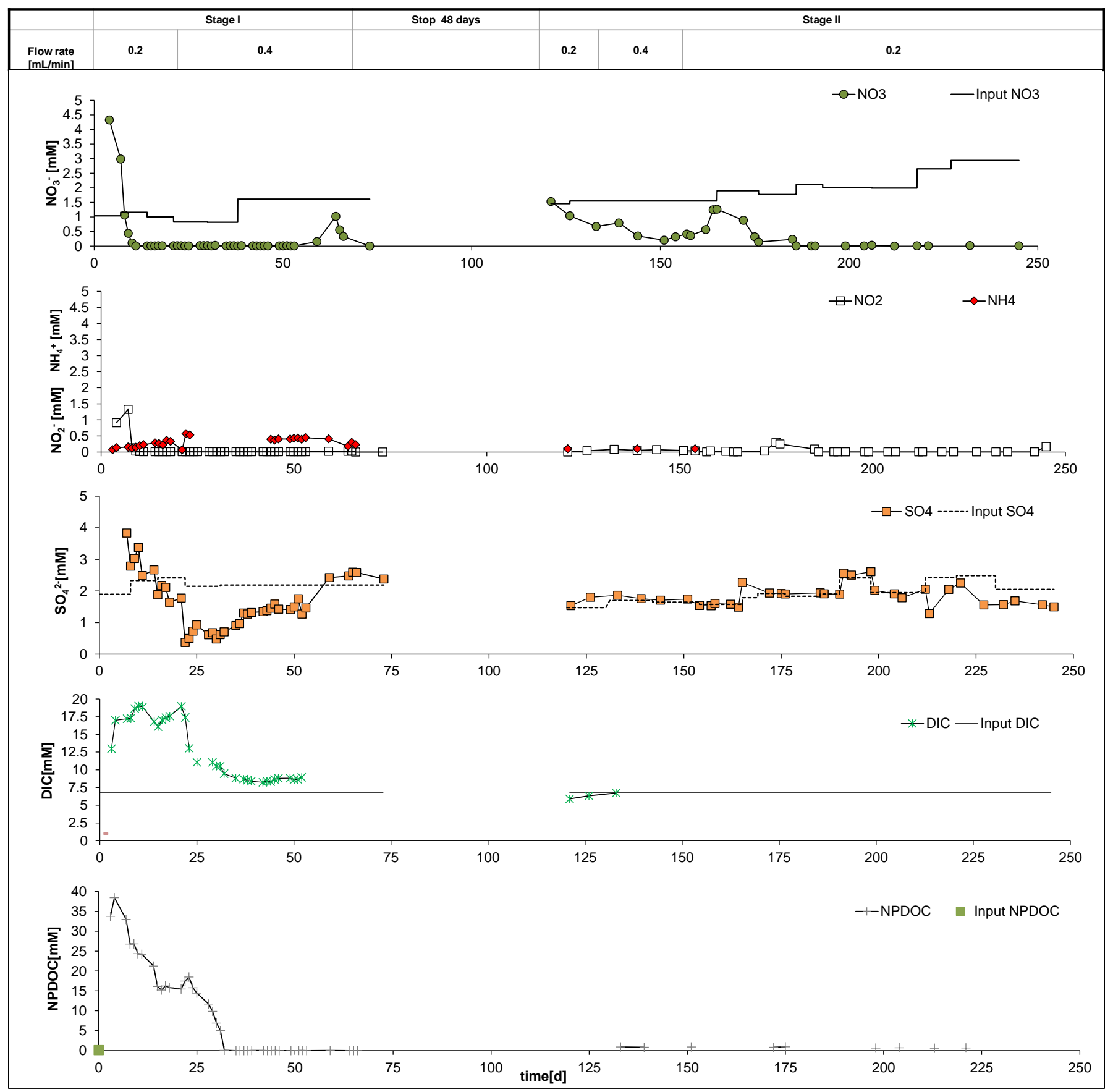




\section{Figure 3}

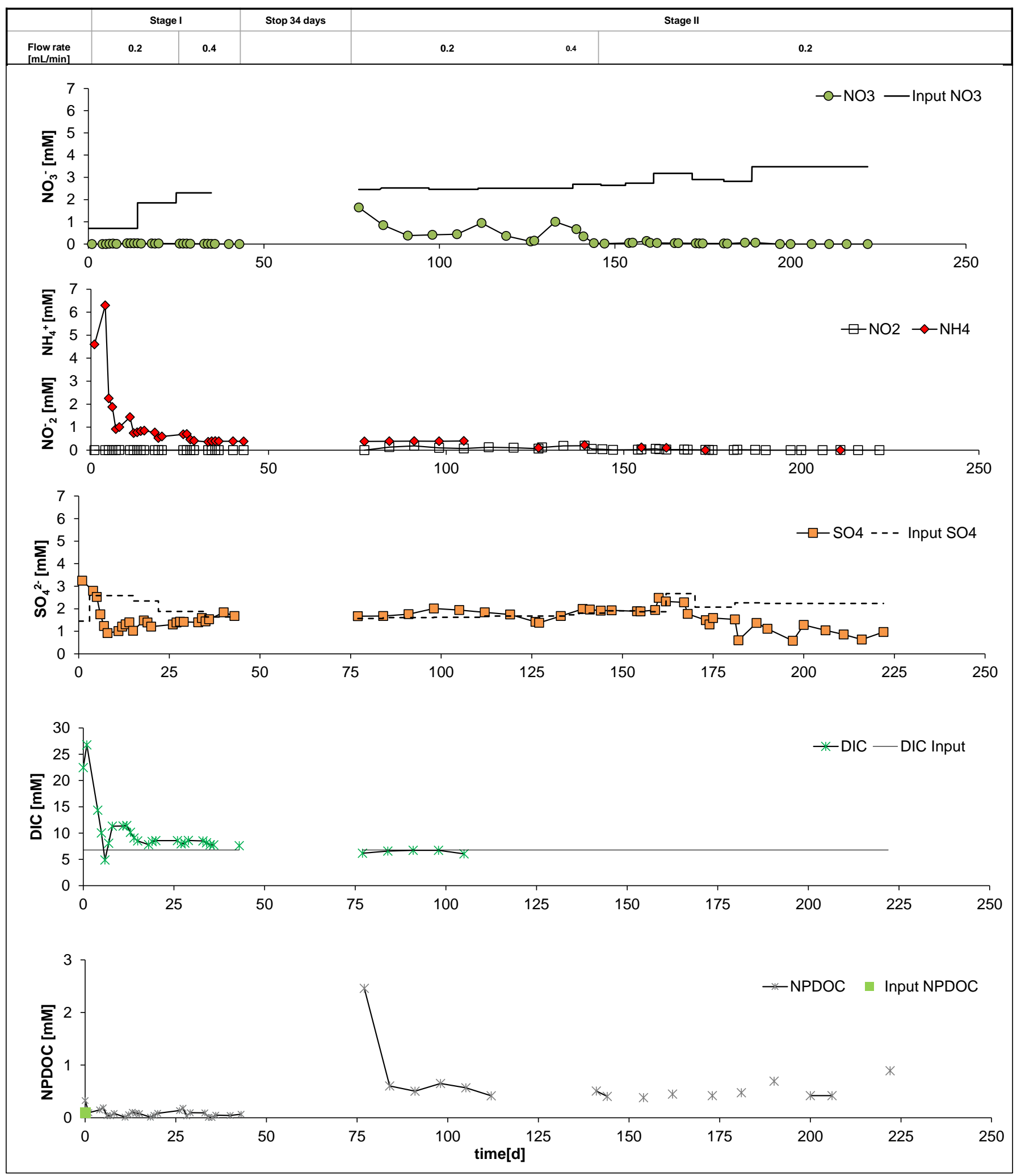


Figure 4
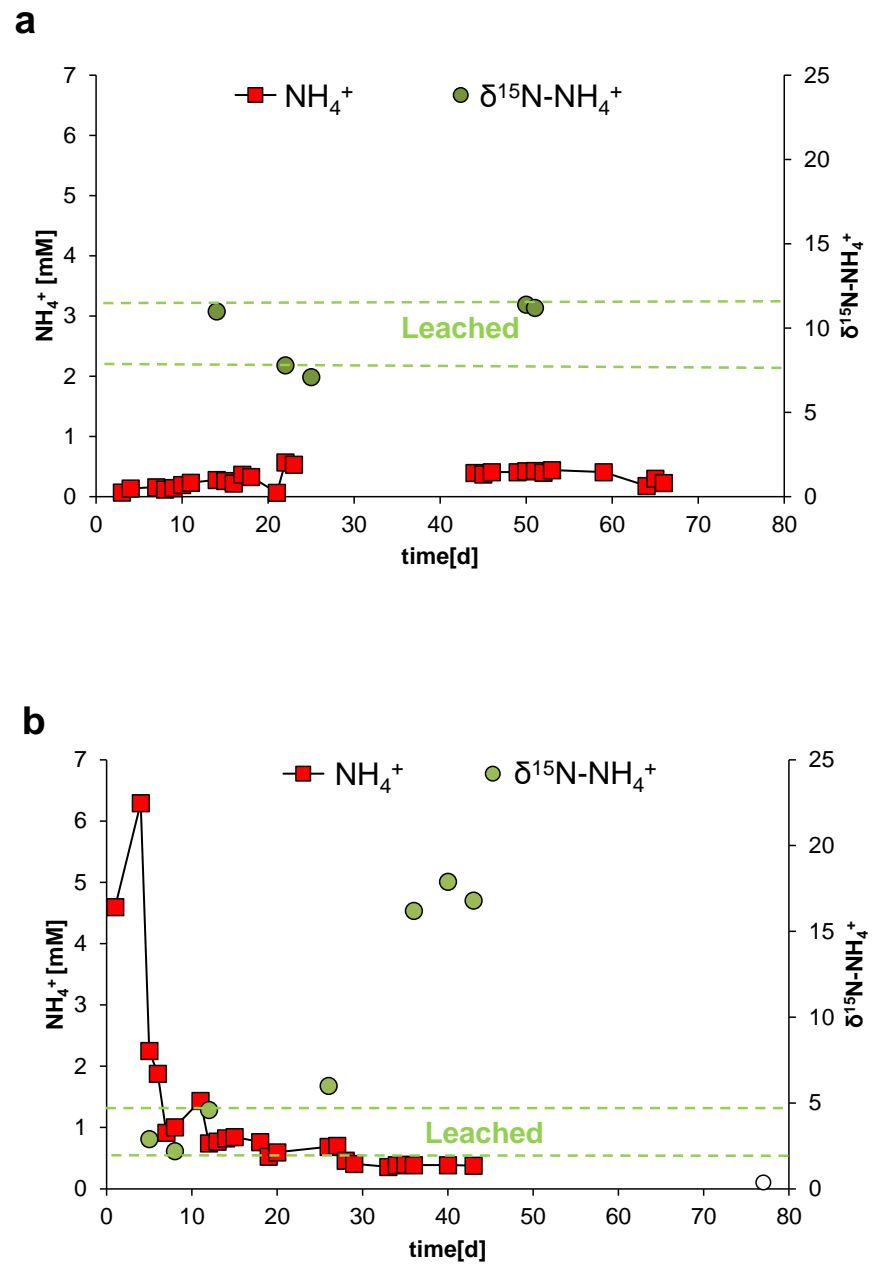
Figure 5

a

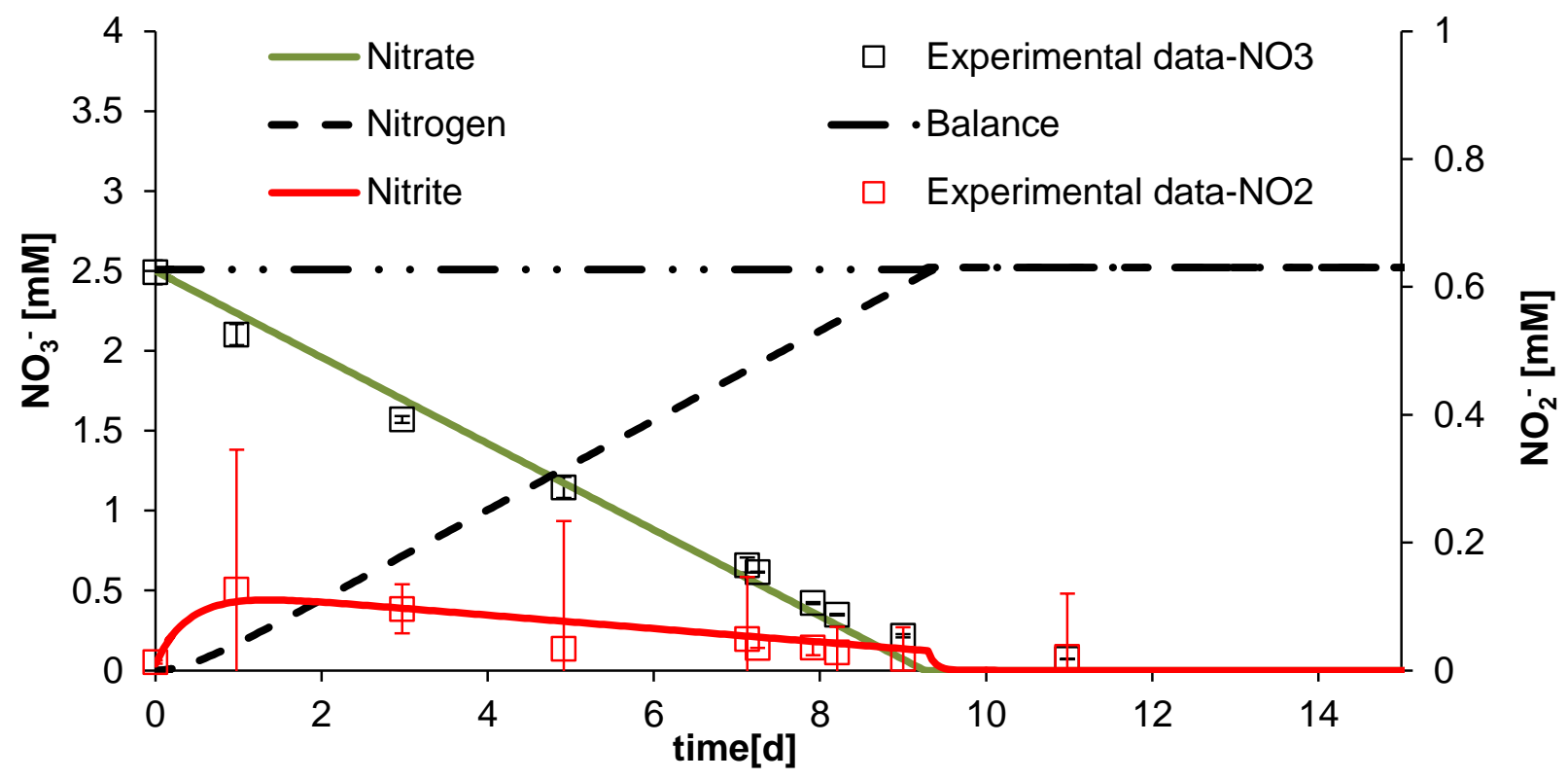

b

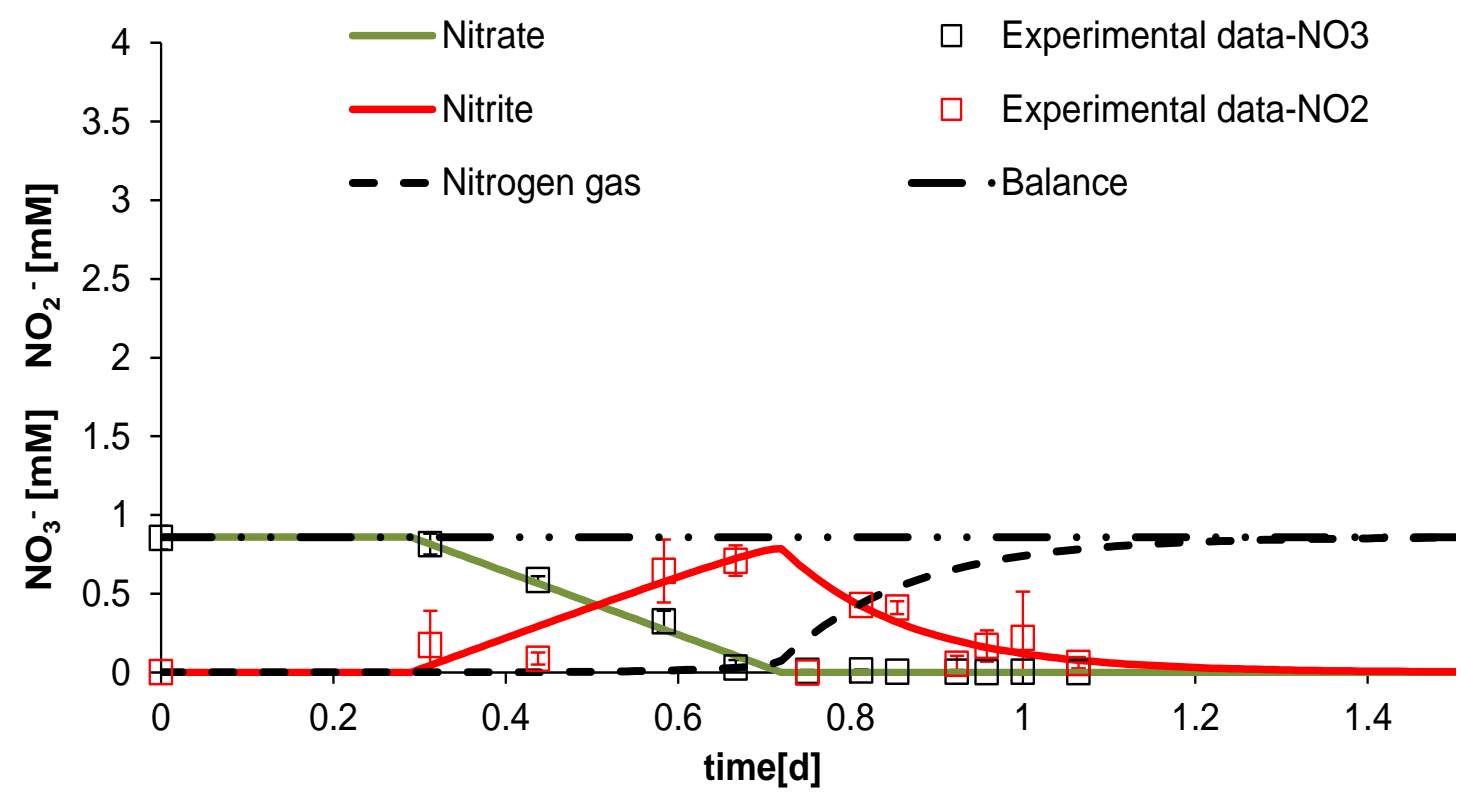


Figure 6
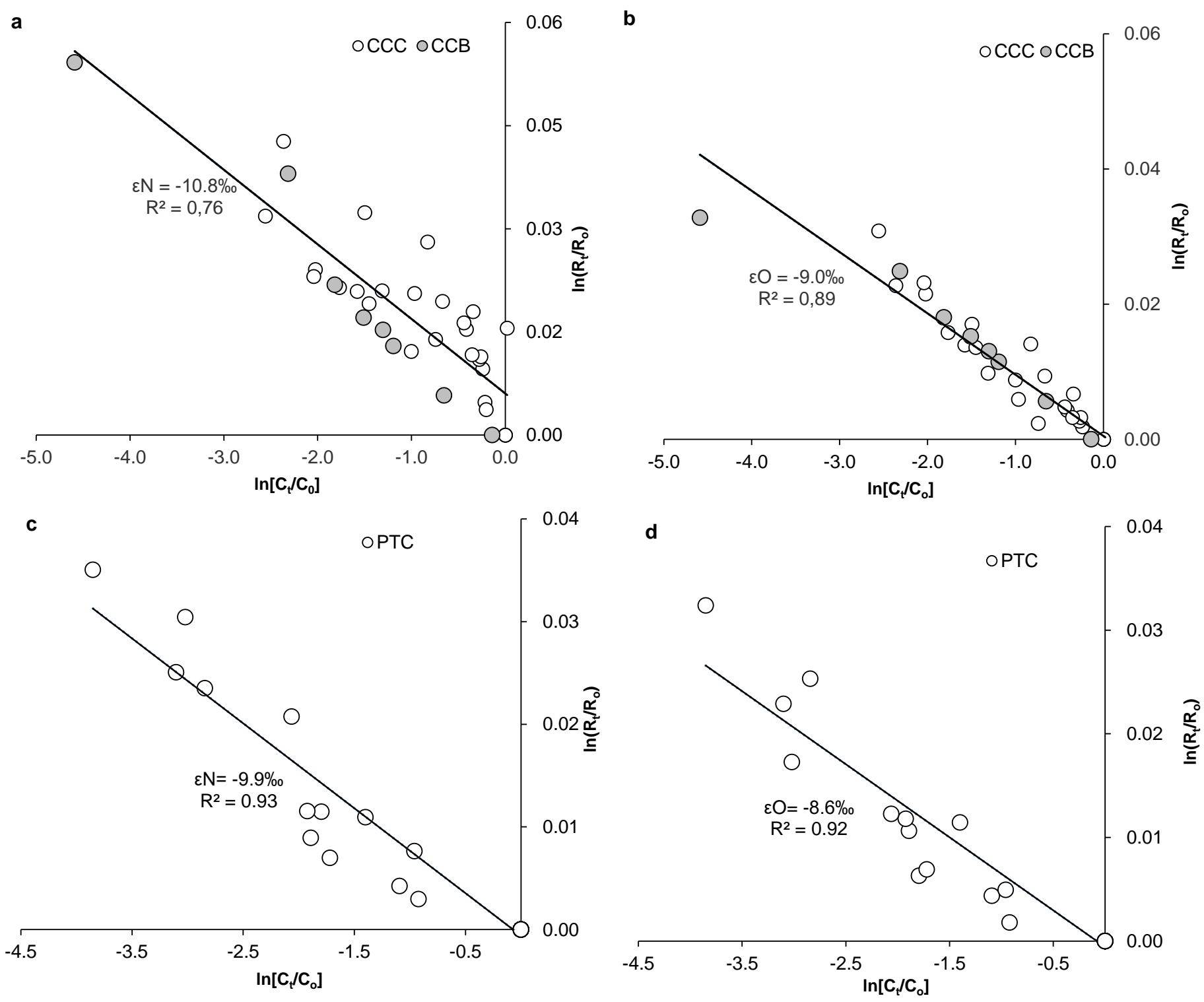
Table 1. Summary of key parameters of both organic substrates used in the present experiments: commercial compost (CC) and palm tree leaves (PT)

\begin{tabular}{ccccc}
\hline Organic substrate & $\mathbf{N}(\%)$ & $\mathbf{C}_{\text {total }}(\%)$ & $\boldsymbol{\delta}^{15} \mathbf{N}(\%)$ & $\boldsymbol{\delta}^{13} \mathbf{C}(\%)$ \\
\hline CC & $1.0 \pm 0.2$ & $15.1 \pm 1.1$ & $12.1 \pm 1.1$ & $-25.1 \pm 0.2$ \\
PT & $1.5 \pm 0.6$ & $47.4 \pm 0.9$ & $3.6 \pm 0.8$ & $-27.1 \pm 0.2$ \\
\hline
\end{tabular}


Table 2. Experimental conditions of the commercial compost (CCB), sterilized control (SCB), palm tree leaves (PTB) and absence control (ACB) batch experiments

\begin{tabular}{|c|c|c|}
\hline Code & Experiment & Contents of the incubation \\
\hline CCB & $\begin{array}{c}\text { Triplicate } \\
(1,2,3)\end{array}$ & $\begin{array}{c}20 \mathrm{~g} \text { commercial compost, } 400 \mathrm{~mL} \text { groundwater, } 0.80 \\
\mathrm{mM} \mathrm{NO}_{3}^{-}\end{array}$ \\
\hline SCB & $\begin{array}{l}\text { Sterilized } \\
\text { control }\end{array}$ & $\begin{array}{c}11 \mathrm{~g} \text { autoclaved crushed palm leaves, } 400 \mathrm{~mL} \text { sterilized } \\
\text { groundwater, } 0.80 \mathrm{mM} \mathrm{NO}_{3}^{-}\end{array}$ \\
\hline PTB & $\begin{array}{c}\text { Triplicate } \\
(1,2,3)\end{array}$ & $11 \mathrm{~g}$ palm leaves, $400 \mathrm{~mL}$ groundwater, $0.80 \mathrm{mM} \mathrm{NO}_{3}^{-}$ \\
\hline ACB & $\begin{array}{l}\text { Absence } \\
\text { control }\end{array}$ & $400 \mathrm{~mL}$ groundwater, $0.80 \mathrm{mM} \mathrm{NO}_{3}^{-}$ \\
\hline
\end{tabular}


Table 3. Kinetic parameters used for modelling batch experiments

\begin{tabular}{cccc}
\hline \multirow{2}{*}{ Experiment } & $\begin{array}{c}\mathrm{NO}_{3}^{-} \text {to } \\
\mathbf{N O}_{2}^{-}\end{array}$ & \multicolumn{2}{c}{$\mathbf{N O}_{\mathbf{2}}{ }^{-}$to $\left.\mathbf{N}_{\mathbf{2}} \mathbf{g}\right)$} \\
\cline { 2 - 4 } & $\mathrm{K}_{\mathbf{1}}\left(\mathbf{m M ~ d}^{-1}\right)$ & $\left.\mathbf{K}_{\mathbf{2}} \mathbf{( d}^{-1}\right)$ & $\mathbf{K}_{\mathbf{i}}(\mathbf{m M})$ \\
\hline CCB & 0.27 & 9 & 0.8 \\
PTB & 2 & 6.5 & 0.01 \\
\hline
\end{tabular}


Table 4. Estimated isotopic enrichment factor $(\varepsilon N$ and $\varepsilon O)$ obtained in this study and reported in the literature for denitrification lab experiments.

\begin{tabular}{|c|c|c|c|c|c|}
\hline & $\varepsilon N(\%)$ & $\varepsilon O(\%)$ & $\varepsilon N / \varepsilon O$ & Reference & Commnets \\
\hline \multicolumn{6}{|c|}{ Heterotrophic denitrification } \\
\hline \multirow{12}{*}{ Pure cultures } & -20 to -30 & n.d. & n.d. & Wellman et al. (1968) & Batch, Penassay Broth medium, Psedumonas stutzeri \\
\hline & -13.4 to -20.8 & n.d. & n.d. & Delwiche and Steyn (1970) & Batch, glucose, Pseudomonas denitrificans \\
\hline & -28.6 & n.d. & n.d. & Barford et al. (1999) & Steady-state reactor, acetate, Paracoccus denitrificans \\
\hline & -39 to -31 & +13 to +32 & n.d. & Toyoda et al. (2005) & Batch, citrate, Pseudomonas fluorescens \\
\hline & -22 to -17 & -3 to -1 & n.d. & Toyoda et al. (2005) & Batch, citrate, Pseudomonas fluorescens \\
\hline & -22 to -10 & +4 to +23 & n.d. & Toyoda et al. (2005) & Batch, citrate, Paracoccus denitrificans \\
\hline & -12.7 & n.d. & n.d. & Sutka et al. (2006) & Batch, citrate, Pseudomonas chlororaphis \\
\hline & -36.7 & n.d. & n.d. & Sutka et al. (2006) & Batch, citrate, Pseudomonas chlororaphis \\
\hline & -18.1 and -17.3 & -16.5 and -16.1 & 1.07 to $1.09^{*}$ & Wunderlich et al. (2012) & Batch, toluene, Thauera aromatica and Aromatoleum aromaticum \\
\hline & -18.9 & -15.9 & $1.19^{*}$ & Wunderlich et al. (2012) & Batch, benzoate, Thauera aromatica \\
\hline & -22.1 and -23.5 & -19.9 and -23.7 & 1.0 to $1.1^{*}$ & Wunderlich et al. (2012) & Batch, acetate, Thauera aromatica and Aromatoleum aromaticum \\
\hline & -8.6 and -16.2 & -4.0 and -7.3 & 1.26 to 2.94 & Knöller et al. (2011) & Batch, succinate and toluene, Azoarcus sp. and Ps. pseudoalcaligenes \\
\hline Seawater & -5.4 to -26.6 & -4.8 to -22.6 & 1.0 to 1.8 & Granger et al. (2008) & Batch, seawater, pure cultures \\
\hline \multirow{3}{*}{$\begin{array}{l}\text { Freshwater } \\
\text { sediment }\end{array}$} & -14.6 & n.d. & n.d. & Grischek et al. (1998) & Column, sediment from sandy silty and gravel aquifer and river water \\
\hline & -32.9 to -34.1 & n.d. & n.d. & Tsushima et al. (2006) & Column, aquifer sediment and groundwater \\
\hline & -11.6 and -15.7 & -12.1 and -13.8 & 0.96 to 1.14 & Carrey et al. (2013) & Column, organic- and sulfide-rich sediments and groundwater \\
\hline \multirow{6}{*}{$\begin{array}{c}\text { Freshwater } \\
\text { sediment } \\
\text { bioestimulated }\end{array}$} & -17.1 & -15.1 & 1.1 & Vidal-Gavilan et al. (2013) & Batch, aquifer material and groundwater + glucose \\
\hline & -13 & -8.9 & 1.5 & Vidal-Gavilan et al. (2013) & Batch, aquifer material and groundwater + ethanol \\
\hline & -6.5 & -6 & 1.01 & Vidal-Gavilan et al. (2014) & Column, aquifer material and groundwater + ethanol \\
\hline & -8.8 & -8 & 1.1 & Carrey et al. (2014) & Column, aquifer sediment and groundwater + glucose \\
\hline & -10.4 & -9 & 1.3 & This study & Column and batch, groundwater + commercial compost \\
\hline & -9.9 & -8.6 & 1.15 & This study & Column, groundwater + palm tree leaves \\
\hline \multicolumn{6}{|c|}{ Autotrophic denitrification } \\
\hline & -15.0 and -22.9 & -19.0 and -13.5 & 1.2 & Torrentó et al. (2010) & Batch, pyrite, pure culture (Th. denitrificans) \\
\hline & -12.6 & -8.8 & 1.43 & Hosono et al. (2015) & Batch, pyrite, pure culture (Th. denitrificans) \\
\hline & -25.0 and -27.6 & -13.5 and -21.3 & 1.3 & Torrentó et al. (2011) & Batch, aquifer sediment + pyrite \\
\hline
\end{tabular}

n.d. = not dertermined, $\left({ }^{*}\right)$ Values estimated from published data 